\author{
UNIVERSIDADE DE SÃO PAULO \\ FACULDADE DE FILOSOFIA, LETRAS E CIÊNCIAS HUMANAS \\ DEPARTAMENTO DE LETRAS ORIENTAIS \\ PROGRAMA DE PÓS-GRADUAÇÃO EM LÍNGUA HEBRAICA, LITERATURA \\ E CULTURA JUDAICAS
}

\title{
A parábola-metáfora na literatura rabínica \\ O mashal à luz dos trabalhos de Paul Ricoeur e Jonáh Fraenkel
}

(Versão corrigida)

PASCAL JEAN ANDRÉ ROGER PEUZÉ

Dissertação apresentada ao

Programa de Pós-Graduação em

Língua Hebraica, Literatura e

Cultura Judaicas do

Departamento de Letras

Orientais da Faculdade de

Filosofia, Letras e Ciências

Humanas da Universidade de São

Paulo, para a obtenção do título

de Mestre em Letras.

Orientador:

Professor Dr. Moacir Amâncio

\section{São Paulo}


AGRADECIMENTOS

ao Prof. Dr. Moacir Amâncio, pelo paciente incentivo,

a Érika e Jacil, pela colaboração na tradução e correção do texto,

a Robin,

pela inspiração,

meus sinceros agradecimentos. 


\section{RESUMO}

PEUZÉ, P.J.A.R. A parábola-metáfora na literatura rabínica, o mashal à luz dos trabalhos de Paul Ricoeur e Jonáh Fraenkel. 2010. 94 f. Dissertação (mestrado). Faculdade de Filosofia, Letras e Ciências Humanas, Universidade de São Paulo, São Paulo, 2010.

A parábola (o mashal) da literatura rabínica é analisada nesta dissertação como uma narrativa metafórica. Pontua-se primeiramente os elementos básicos da teoria de Paul Ricoeur sobre a metáfora e os seus paralelos na concepção do mashal rabínico de Jonáh Fraenkel. Apresenta-se em seguida, por meio de um constante vai-e-vem entre os dois autores, e na base de cinco meshalim, os passos metodológicos desenvolvidos por Fraenkel: determinação do modelo de base, análise da trama da narrativa enquanto unidade completa, estabelecimento de correspondências entre mashal e nimshal. Valoriza-se então a extravagância da parábola que obriga a ir além do modelo de base da mesma. Desta forma, o mashal torna-se para os Sábios da literatura rabínica um meio de desvelar novos sentidos da Torá. Aponta-se enfim que o mashal se encontra em plena consonância com o mundo do Talmud-Torá por ser, antes de tudo, uma atividade e um questionamento, e por pertencer ao domínio da Torá Oral. Assim, ele pode e deve questionar a Torá Escrita. A harmonia de forma e conteúdo, e os diversos temas abordados no mashal, fazem também com que este fosse tão apreciado pelos Sábios nos seus ensinamentos. Por isso, intitulamos a parábola-metáfora que é o mashal rabínico de 'Talmud-Torá em miniatura'.

Palavras-chave: parábola, mashal, metáfora, Paul Ricoeur, Jonah Fraenkel 


\begin{abstract}
PEUZÉ, P.J.A.R. The parable-metaphor in rabbinical litterature, the mashal in light of Paul Ricoeur's and Jonáh Fraenkel's researches. 2010. $94 \mathrm{f}$. Dissertação (mestrado). Faculdade de Filosofia, Letras e Ciências Humanas, Universidade de São Paulo, São Paulo, 2010.
\end{abstract}

The parable (the mashal) of rabbinical literature is analyzed in this dissertation as a metaphoric narrative. First, we point out the main elements of Paul Ricoeur's theory on metaphor and its parallels in Jonah Fraenkel's conception of the rabbinical mashal. We then present, constantly considering both theoretical approaches and on the basis of five meshalim, the methodological steps developed by Fraenkel: determination of the basic model, analysis of the plot within the narrative considered as a complete unit, setting of correspondences betwenn mashal and nimshal. We then insist on the importance of the extravagance in the parable which requires to go beyond the basic model. The mashal becomes thus for the Sages of rabbinical literature a means to uncovering new meanings of the Torah. It is pointed out finally that the mashal is in full harmony with the world of Talmud-Torah, being primarily an activity and a questioning, and belonging to the realm of Oral Torah. Consequently, he can and should question the Written Torah. The harmony of form and content, and the various themes worked out in the mashal also explain why it was highly appreciated by the Sages in their teachings. Therefore, we call a 'Talmud-Torah in miniature' the rabbinical mashal considered as a metaphorical narrative.

Keywords: parable, mashal, metaphor, Paul Ricoeur, Jonah Fraenkel 


\section{RÉSUMÉ}

PEUZÉ, P.J.A.R. La parabole-métaphore dans la littérature rabbinique, le mashal à la lumière des travaux de Paul Ricoeur et Jonah Fraenkel. 2010. $94 \mathrm{f}$. Dissertação (mestrado). Faculdade de Filosofia, Letras e Ciências Humanas, Universidade de São Paulo, São Paulo, 2010.

La parabole (le mashal) de la littérature rabbinique est analysée dans cette dissertation comme une narrative métaphorique. Sont tout d'abord mis en évidence les éléments fondamentaux de la théorie de Paul Ricoeur sur la métaphore et ses parallèles dans la conception de Jonah Fraenkel par rapport au mashal rabbinique. Nous présentons ensuite, faisant un va-et-vient constant entre les deux auteurs, et sur la base de cinq meshalim, les étapes méthodologiques développées par Fraenkel : détermination du modèle de base, analyse de l'intrigue de la narrative en tant qu'unité complète, établissement de correspondances entre mashal et nimshal. Nous nous penchons ensuite sur l'extravagance de la parabole qui oblige à dépasser le modèle de base. C'est de cette manière que le mashal est devenu pour les Sages de la littérature rabbinique un moyen de dévoiler de nouveaux sens dans la Torah. Nous terminons en montrant la pleine consonance du mashal avec le monde du Talmud-Torah, de par son caractère d'activité et de questionnement et de par son appartenance au domaine de la Torah Orale. C'est ainsi qu'il peut et doit questionner la Torah Écrite. L'harmonie de forme et de contenu, et les divers thèmes abordés dans le mashal contribuent également à ce qu'il soit si apprécié par les Sages dans leur enseignement. C'est la raison pour laquelle nous intitulons la parabole métaphorique qu'est le mashal rabbinique un 'Talmud-Torah en miniature'.

Mots-clé: parabole, mashal, métaphore, Paul Ricoeur, Jonah Fraenkel 
SUMÁRIO

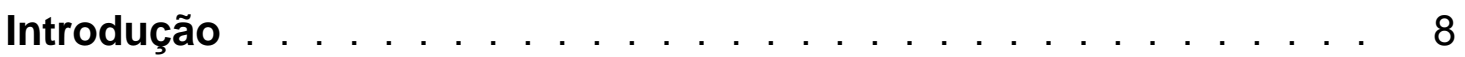

1. TEORIA DA METÁFORA E DA PARÁBOLA EM RICOEUR E DO MASHAL EM FRAENKEL . . . . . . . . . . . . . . . . 12

1.1

teoria de Ricoeur sobre a metáfora viva . . . . . . . . . . . 12

1.1.1 Uma análise semântica da metáfora . . . . . . . . . . 12

a) o enunciado metafórico . . . . . . . . . . . . . . . . 15

b) a impertinência semântica . . . . . . . . . . . . . . . . . . . 15

c) metáfora e comparação . . . . . . . . . . . . . . . . . . 16

1.1.2 Metáfora e realidade - metáfora e referência . . . . . . . 18

$1.1 \quad$ D a metáfora à parábola . . . . . . . . . . . . . . . . . 20

1.2 Jo náh Fraenkel: como abordar o mashal . . . . . . . . . . . . 22

1.3.1 Definição do mashal . . . . . . . . . . . . . . . . 22

1.3.2 O mashal como matéria de estudo . . . . . . . . . 23

2. A ANÁLISE DO MASHAL: MODELO DE BASE E NARRATIVA . . . . . 27

2.1 Distinção mashal, nimshal e derashá . . . . . . . . . . . . . 27

2.20 modelo de base . . . . . . . . . . . . . . . . . . . . 29

2.2.1 Variedade dos modelos de base . . . . . . . . . . . . 30

2.2.2 Análise dos modelos de base . . . . . . . . . . . . . . . . 31

2.2.2.1 Mashal do arrendatário . . . . . . . . . . . . . . . . . . 32

2.2.2.2 Mashal da jarra d'água . . . . . . . . . . . . . . . . . 33

2.2.3 Modelos de base, esquematização, tradicionalidade (Ricoeur) 34

2.2.4 Modelos de base vs diversidade das realidades religiosas . . .36 
2.30 mashal como narrativa $\ldots \ldots \ldots \ldots$

2.3.1 A parábola como narrativa (Ricoeur) . . . . . . . . . . . 36

2.3.2 O mashal como narrativa (Fraenkel) . . . . . . . . . . 38

2.3.3 Exemplos de análise de narrativa . . . . . . . . . . . . 40

2.3.3.1 Mashal do ladrão de morangos . . . . . . . . . . . . . . 40

2.3.3.2 Mashal das vestes reais . . . . . . . . . . . . . . . 41

2.3.3.3 Mashal da jarra d'água . . . . . . . . . . . . . . . . . . 42

2.3.3.4 Mashal da raposa e dos peixes . . . . . . . . . . . . 43

3. MASHAL VS NIMSHAL E A EXTRAVAGÂNCIA DA PARÁBOLA . . . 46

3.1 Mashal vs nimshal - Referência . . . . . . . . . . . . . . 46

3.2 A extravagância do mashal - Para além do modelo de base . . . . . 48

3.3 Estabelecimento de correspondências e extrapolação do modelo de base . . . . . . . . . . . . . . . . . . 49

3.3.1 Mashal da jarra d'água $\ldots \ldots \ldots$

3.3.2 Mashal das vestes reais . . . . . . . . . . . . . . . . . 50

3.3.3 Mashal da raposa e dos peixes . . . . . . . . . . . . . . . 52

3.3.4 Mashal do arrendatário . . . . . . . . . . . . . . . . . . . 54

3.3.5 Mashal do ladrão de morangos . . . . . . . . . . . . . 55

4. O MASHAL DESVELA A TORÁ $\ldots \ldots \ldots \ldots \ldots$

4.1 A metáfora e a parábola inovam . . . . . . . . . . . . 58

4.2 Exemplos de desvelamento nos meshalim . . . . . . . . . . . 59

4.2.1 Mashal do ladrão de morangos . . . . . . . . . . . . . . 59

4.2.2 Mashal do arrendatário . . . . . . . . . . . . . . . . . 60

4.2.3 Mashal da jarra d'água . . . . . . . . . . . . . . . . . . 61

4.2.4 Mashal das vestes reais . . . . . . . . . . . . . . . . . . . . 62

4.2.5 Mashal da raposa e dos peixes . . . . . . . . . . . . 63

5. O MASHAL: UM TALMUD-TORÁ EM MINIATURA . . . . . . . . . . 66 
5.1 Introdução . . . . . . . . . . . . . . . . . . . . . 66

5.2 Mashal e Talmud-Torá . . . . . . . . . . . . . . . . . . 67

5.2.1 Uma atividade e um questionamento. . . . . . . . . . . . . 67

5.2.2 Relação entre mashal, Torá escrita e Torá oral . . . . . . . 70

5.3 O mashal: harmonia de forma e de conteúdo . . . . . . . . . . . 72

5.4 O mashal reflete os temas do Talmud-Torá . . . . . . . . . . . . 74

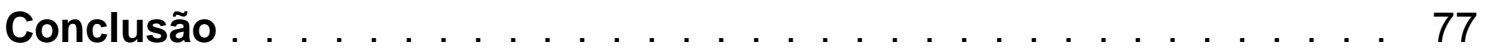

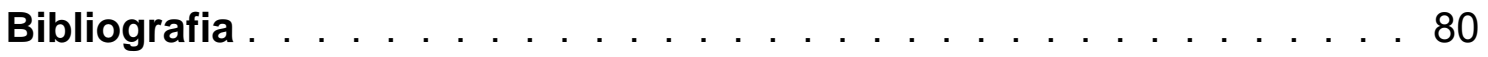

Anexo: Textos originais dos meshalim e suas traduções . . . . . . . . . . 87 


\section{INTRODUÇÃO}

"O mashal é um dos fundamentos mais importantes da Agadá ${ }^{1}$ e uma das suas formas literárias mais apreciadas" afirmava Wilhelm Bacher no início do século $X X{ }^{2}$ É provavelmente por esta razão que temos centenas de parábolas na literatura rabínica clássica, i.e., na Mishná, nos dois Talmudim e nos antigos midrashim.

Desde Bacher, a abordagem das parábolas passou por várias fases. Alguns pesquisadores insistiram sobre o contexto histórico-real dos textos. 0 conhecimento do mundo real e exterior ao mashal auxilia em sua compreensão. O mashal, por sua vez, é considerado como uma fonte histórica que permite melhor conhecer o Israel da época talmúdica. ${ }^{3} \mathrm{O}$ estruturalismo desenvolveu outra abordagem, aplicada sobretudo às parábolas do Novo Testamento. Trata-se de discernir o sistema de liames e coerências, oposições e rupturas, equilíbrio entre os diversos elementos que compõem a estrutura, tanto do texto quanto da realidade.

Outra via coloca a linguagem no âmago da experiência humana, e postula não haver compreensão de si que não seja mediada pela comunicação, pelos símbolos, pelos textos: a linguagem articula, clarifica a experiência pessoal e mostra-se capaz de revelar ao ser humano sua realidade. Ela aparece assim portadora de uma função hermenêutica essencial. Nesta ótica, numerosas pesquisas levaram a considerar a teoria moderna da metáfora como o instrumento lingüístico mais adequado a esta função hermenêutica e inovadora da linguagem. O próprio título desta dissertação indica que é esta

\footnotetext{
${ }^{1}$ Costuma-se dividir a literatura rabínica em dois gêneros: a Agadá que abrange os textos de reflexão teológica, as homilias, as máximas, parábolas, comentários diversos, e a Halakhá, textos de caráter normativo que tratam dos mandamentos e sua prática.

${ }^{2}$ Cf. BACHER citado por FRAENKEL (1991, p. 323).

${ }^{3}$ Um exemplo típico é o estudo de ZIEGLER (1903) no qual as parábolas de rei são expostas à luz da época romana. A obra de LIEBERMAN (1950) sobre o helenismo na Palestina do período talmúdico inscreve-se igualmente nesta perspectiva.
} 
hipótese que será aqui estudada: a parábola, bem como o mashal rabínico, são, em sua natureza, metáforas.

Neste trabalho, a teoria que ancora a análise dos meshalim é aquela exposta por Paul Ricoeur em sua obra A Metáfora Viva, publicada em 1975, mas também nos três volumes de Tempo e Narrativa (1983-1985) nos quais ele trata da função narrativa. Nós nos apoiaremos também sobre um longo artigo no qual nosso autor se debruça de maneira mais específica sobre a linguagem religiosa (inclusive as parábolas): Biblical Hermeneutics, publicado em 1975 na revista Semeia. ${ }^{4}$

Esta dissertação segue também os trabalhos de Jonáh Fraenkel, professor emérito da Universidade Hebraica de Jerusalém. Fraenkel alia um conhecimento aprofundado das fontes talmúdicas a uma familiaridade com as teorias modernas de análise literária. Grande parte dos seus trabalhos é consagrada à agadá, da qual ele é considerado hoje um dos mais eminentes especialistas.

Fraenkel consagrou um capítulo ao mashal rabínico em sua obra Darkhei haAgadá ve haMidrash (As vias da Agadá e do Midrash), publicada em 1991, bem como no seu livro de cunho mais didático Midrash veAgadá (Midrash e Agadá) (1996). Faremos igualmente referência a outra obra, mais técnica, intitulada Sipur haAgadá, Ahdut shel Tokhen veTsura (A Narrativa Agádica, harmonia de forma e conteúdo) publicada em 2001.

Nessas páginas consagradas às parábolas, Fraenkel menciona Ricoeur uma única vez, e em nota de rodapé: "Apoiamo-nos aqui principalmente sobre análise de Paul Ricoeur em Biblical Hermeneutics ${ }^{5}$ (FRAENKEL, 1991, p. 645, nota 25, tradução nossa). Em duas passagens não ligadas diretamente às parábolas, Fraenkel se refere à opinião de Ricoeur a respeito do caráter hermenêutico da linguagem, em oposição à concepção estruturalista. (Id., 2001, p. 78 e p. 131-2). Porém, apesar da escassez de referências a Ricoeur, a

\footnotetext{
${ }^{4}$ Traduzido para o português no livro: A hermenêutica bíblica. Tradução de Paulo Meneses. São Paulo: Loyola, 2006, p. 133-223.

5 "אנו מסתמכים כאן בעיקר על ניתוחו של פ' ריקור
} 
relação entre os trabalhos dos dois autores é muito estreita, como veremos no decorrer desta dissertação, fazendo um vai-e-vem constante entre as suas posições. Poderemos constatar que os elementos teóricos de Ricoeur encontram sua aplicação prática nas análises feitas por Fraenkel, com um enriquecimento considerável. Fraenkel, por sua vez, confirma em múltiplos exemplos, a pertinência das afirmações de Ricoeur sobre a metáfora e a parábola-metáfora.

Este constante vai-e-vem permitirá colocar em evidência a natureza hermenêutica, o funcionamento e o objetivo do mashal rabínico, e assim melhor compreender porque ele ocupou um lugar privilegiado na literatura dos Sábios da época talmúdica.

O primeiro capítulo será consagrado à exposição da teoria da metáfora e da parábola-metáfora, segundo Ricoeur, que se encontra espelhada na teoria do mashal desenvolvida por Fraenkel.

Nos três capítulos seguintes, exporemos os passos metodológicos elaborados por este último a partir das teorias da metáfora e da narrativa. Este método assaz didático permite uma análise mais precisa e pertinente dos meshalim, respeitando sua natureza hermenêutica.

No quinto e último capítulo será posta em evidência a profunda consonância entre o mashal e o mundo do Talmud-Torá, o estudo-ensinamento da Torá oral e escrita. Esta consonância peculiar explica porque o mashal se tornou um instrumento privilegiado dos Sábios de Israel.

Indicamos acima que faremos um vai-e-vem constante entre a teoria de Ricoeur e as pesquisas de Fraenkel. Apoiarmo-nos sobre cinco meshalim rabínicos, dos quais quatro são trabalhados por Fraenkel, a fim de ilustrar a teoria por meio de exemplos precisos. Eles foram escolhidos em função da diversidade das suas fontes, dos temas abordados, de sua composição. A exposição que faremos desses meshalim desenrolar-se-á de maneira gradativa, ao longo dos cinco capítulos. 
As próprias narrativas, traduzidas para o português, são introduzidas no corpo da dissertação. No anexo, encontra-se a versão original em hebraico, acompanhada da respectiva tradução.

As cinco parábolas escolhidas são as seguintes:

- "Mashal do ladrão de morangos" 6

- "Mashal das vestes reais" 7

- "Mashal do arrendatário" 8

- "Mashal da jarra d'água" 9

- "Mashal da raposa e dos peixes" 10

Uma sexta parábola é mencionada a fim de ilustrar a concepção que os próprios Sábios de Israel tinham desse tipo de narrativa:

- "Mashal do pavio" 11

Esses meshalim - de uma simplicidade desconcertante - nos levarão a perceber a riqueza e a sutileza de um gênero literário particularmente apreciado pelos Sábios. Essa simplicidade é apenas aparente.

\footnotetext{
${ }^{6}$ Midrash Bereshit Rabbá, parashá 22, 9; FRAENKEL, 1991, p. 324-5; 336-7; 1996, p. 418.

${ }^{7}$ Talmud da Babilônia, Tratado Shabat, 152b.

${ }^{8}$ Midrash Bereshit Rabbá, parashá 22, 5; Ibid., p. 332; 1996, p. 412, 428-9.

${ }^{9}$ Mishná Suká 2,9; Ibid., p. 360;1996, p. 409.

${ }^{10}$ Talmud da Babilônia, tratado Berakhot 61b; Ibid, p. 351; 1996, p. 440-2.

${ }^{11}$ Shir haShirim Rabá,1,1; Ibid, p. 327-8.
} 


\section{CAPÍTULO I}

\section{TEORIA DA METÁFORA E DA PARÁBOLA-METÁFORA EM \\ PAUL RICOEUR E DO MASHAL EM JONÁH FRAENKEL}

\subsection{A TEORIA DE RICOEUR SOBRE A METÁFORA VIVA}

Apresento aqui elementos básicos da teoria de Ricoeur a partir da Metáfora Viva e do artigo Hermenêutica Bíblica. As linhas principais serão apresentadas em função de sua correspondência e de sua aplicabilidade à questão da parábola.

Ricoeur começa por definir assim a parábola: "A parábola, parece-me, é a conjunção de uma forma narrativa e de um processo metafórico" (2006, p. 134, grifo do autor). Aquilo que nos interessa particularmente aqui é compreender o que Ricoeur entende por processo metafórico.

\subsubsection{UMA ANÁLISE SEMÂNTICA DA METÁFORA}

A primeira tese essencial dos trabalhos de Ricoeur sobre este tema é o deslocamento da reflexão da metáfora como vocábulo isolado à metáfora como frase e como discurso. É nesta condição que a reflexão sobre a metáfora pode enriquecer a análise da parábola, sendo esta uma pequena narrativa e não apenas um vocábulo isolado.

No primeiro estudo da Metáfora Viva, Ricoeur parte da definição elaborada por Aristóteles que determinará a compreensão do que é uma 
metáfora durante séculos. Esta definição, citada pelo nosso autor, é assim formulada:

\begin{abstract}
A metáfora é a transferência para uma coisa de um nome que designa uma outra coisa, transferência ou do gênero para a espécie, ou da espécie para o gênero, ou da espécie para a espécie, ou segundo a relação de analogia (Id., 1975, p. 19, tradução nossa).
\end{abstract}

Assim, a estrutura da metáfora é marcada por uma transferência. Dizer por exemplo do herói Aquiles: 'o leão se lançou' mostra esta transferência do vocábulo leão da espécie animal para a espécie humana. Esta transferência é uma predicação a respeito de Aquiles que cria um efeito de surpresa. Notemos que a comparação: 'Aquiles se lançou como um leão' atenuaria ou mesmo perderia este efeito de surpresa. Não seria uma metáfora propriamente dita.

O título do primeiro estudo 'Entre retórica e poética: Aristóteles' é de grande importância, pois coloca a metáfora e a concepção da mesma entre dois pólos diferentes: de um lado a retórica, e de outro a poética.

A retórica clássica visa três coisas: a) o ornamento do discurso, sua elegância, b) a introdução de provas no discurso, c) a persuasão. Inserida no tratado sobre a retórica, a metáfora (e em seguida a parábola se esta lha for assimilada) equivaleria então a uma figura do discurso destinada a influenciar.

O segundo pólo é a poiêsis, outro tratado de Aristóteles onde se encontra igualmente a definição da metáfora. Esta parece então ter duas funções diferentes: uma retórica, e outra poética. A função poética da metáfora não teria neste caso muito a ver com a persuasão. Ela seria mais, retomando o vocábulo poiêsis, uma representação das ações humanas. Ricoeur cita Aristóteles: "Pode-se imitar narrando... ou apresentando todas as personagens tanto agindo (hos prattontas) quanto em ato (energountas) (1448 a 24)" (Id., 2000, p. 74).

O termo imitar / imitação traduz aqui mímesis que não deve ser entendido pura e simplesmente como imitar. A mímesis é a produção original de um mythos, este quadro da humanidade que convida a um ultrapassar, e não a uma simples reprodução da realidade. Trata-se então da "interpretação 
do real pela representação (ou 'imitação') literária", como diz Erich Auerbach na sua obra Mímesis (AUERBACH, 1968, p. 549).

O título do segundo estudo da Metáfora Viva, 'O declínio da retórica: a tropologia', é revelador do destino que foi reservado à metáfora, segundo Ricoeur. A dupla pertença da metáfora, tanto à retórica quanto à poética, não foi mantida como deveria. A percepção e a recepção da metáfora foram feitas essencialmente pelo viés da retórica. Além disto, a retórica de Aristóteles e seus três elementos citados acima viram-se reduzidos progressivamente a questões de elocução (ornamento de discurso), e depois a uma classificação das figuras de discurso, uma tropologia. Falar do 'fogo do amor' ou do 'espelho das águas' é decerto uma metáfora, na qual a retórica verá um desvio entre o sentido literal e o sentido figurado. Mas a análise retórica pára aí. $\mathrm{Na}$ perspectiva desta análise, uma parábola rabínica, por exemplo, utilizaria o vocábulo rei para designar Deus, passando do sentido literal de rei, a um sentido figurado, sem, no entanto, ir mais adiante na análise.

Segundo Ricoeur, este tratamento retórico empobrece a metáfora, pois neste caso, ela não traz nenhuma informação nova, ela nada ensina. A razão deste empobrecimento reside no fato de que a focalização sobre o vocábulo, a ditadura da palavra segundo os termos de Ricoeur, reduz a metáfora a uma função denominativa e não predicativa. A primeira designa uma coisa por um novo nome (o fogo do nosso exemplo, o 'fogo do amor' substitui ardor; ou ainda, o vocábulo rei em uma parábola substitui o nome Deus).

Enquanto a função denominativa vem qualificar a coisa ou a pessoa, a metáfora, por sua vez, não nomeia, mas caracteriza o que já está nomeado, e, neste sentido, ela é portadora de uma informação nova que não está contida na simples denominação. A função da metáfora, como a função da parábola, não seria então meramente decorativa, i.e., retórica no sentido limitado da palavra, mas sim predicativa.

Nos três estudos seguintes ('A metáfora e a semântica do discurso'; 'A metáfora e a semântica da palavra'; 'A metáfora e a nova retórica'), Ricoeur expõe o ponto nevrálgico dos seus trabalhos sobre a metáfora: a fim de abrangê-la corretamente, convém antes de tudo passar da teoria da metáfora- 
palavra à teoria da metáfora-enunciado. Para Ricoeur, a palavra não é o essencial na produção do sentido, pois ela não possui significado em si. Somente o contexto e o discurso conferem à palavra um ou vários sentidos. Nosso autor adota a distinção entre semântica e semiótica. Esta última focaliza-se sobre a palavra como sinal no código lexical, na língua, ao passo que a semântica foca a frase como portadora de significado minimal. Assim sendo, ela se apoia sobre o discurso e a linguagem, e não sobre a língua e o seu código.

Um deslocamento considerável é então operado quando se compara o tratamento retórico e o tratamento semântico da metáfora.

\section{a) O enunciado metafórico}

Já notamos acima que a metáfora está ligada à predicação e não à simples denominação. Esta distinção se dá na diferença dos dois tratamentos. Logicamente, é no enunciado que se coloca esta predicação e não no simples signo que é a palavra. Enquanto a metáfora como tropo podia ser vista como "transposição de um nome estranho a outra coisa" segundo a retórica antiga e clássica (RICOEUR, 2000, p. 107), a teoria semântica considera que "é o enunciado inteiro que constitui a metáfora, mas a atenção concentra-se em uma palavra particular cuja presença justifica que se considere o enunciado metafórico" (Ibid., p. 135). É no enunciado que a produção do sentido metafórico acontecerá. Isto abre evidentemente a via para a parábola como um possível enunciado no qual se desabrochará a metáfora, a tal ponto que falarse-á de parábola-metáfora.

\section{b) A impertinência semântica}

A teoria clássica via na metáfora um desvio de sentido, um acidente da denominação, sendo o pressuposto que uma palavra tenha um sentido literal, do qual se distancia para passar a um sentido figurado (falar de um anjo azul, por exemplo, ou ainda da garganta de uma montanha). Para Ricoeur, a palavra não tem um sentido em si e, conseqüentemente, não tem um suposto sentido literal oposto a um sentido figurado. Não se trata, pois, de um desvio do literal 
para o figurado, mas, na produção metafórica que se apoia sobre o discurso, de uma torsão do termo, segundo a expressão de nosso autor. Ele prossegue:

Somos obrigados a dar uma nova significação à palavra, uma extensão de significação que lhe permite fazer sentido onde uma interpretação literal não faz sentido. Assim, a metáfora aparece como uma resposta a uma certa inconsistência do enunciado interpretado literalmente. Podemos chamar essa inconsistência de "impertinência semântica". (Id., 2006, p. 170)

Ricoeur opera então uma virada radical com relação à retórica clássica. Esta considerava a metáfora como desvio; nosso autor, graças à passagem da palavra ao enunciado, afirma que

A metáfora não é o próprio desvio, mas a redução de desvio. Só há desvio quando se tomam as palavras no seu sentido literal. $A$ metáfora é o procedimento em que o locutor reduz o desvio ao mudar o sentido de uma palavra. (Id., 2000, p. 236)

Ele prossegue, citando Jean Cohen: "A metáfora intervém para reduzir o desvio criado pela impertinência" (op.cit.)

Veremos que pela parábola será criada uma 'impertinência' na narrativa. Com efeito, a narrativa parabólica tomará às vezes aspectos extravagantes, não compreensíveis. Será igual e paradoxalmente o papel da parábola reduzir a impertinência desta mesma narrativa?

\section{c) Metáfora e comparação}

Outra virada radical é sublinhada por Ricoeur no sexto estudo intitulado 'O trabalho da semelhança', no qual ele trata, entre outros pontos, do liame entre metáfora e comparação.

A metáfora foi, por muito tempo, considerada como uma comparação abreviada. Nosso autor se apoia sobre o exemplo da comparação-similitude 'Tiago é estúpido como um burro', que parece reduzida na metáfora 'Tiago é um burro', ou ainda 'que burro!'.(Ibid., p. 285-6). Ricoeur inverte a perspectiva, pelo fato da metáfora afirmar 'isto [é] aquilo'. 
Essa aplicação de um predicado, malgrado a inadequação, constitui a instrução que a metáfora profere. A comparação já é alguma coisa a mais, é uma paráfrase que detém a força da atribuição insólita. [...] A metáfora [...] não é simplesmente a forma abreviada [da comparação], mas, bem ao contrário, o princípio dinâmico. (Ibid., p. 303)

Este princípio dinâmico da metáfora faz com que o ouvinte perceba uma incompatibilidade entre os termos, ou uma impertinência do discurso, como foi assinalado no ponto anterior. É precisamente esta impertinência, esta inconveniência que a metáfora procura. Ao contrário, a comparação não mostra tal impertinência, pois todos os termos conservam seu sentido: Tiago não é um asno, ele é besta como um asno.

Esta diferença entre metáfora e comparação toca diretamente a parábola. Se esta não fosse senão uma comparação desenvolvida (como aliás poderia nos levar a crer a expressão tão típica utilizada nas parábolas: isto é semelhante a), ela operaria pura e simplesmente no domínio de uma substituição. Falar, por exemplo, de um reino humano, para designar na realidade um reino divino.

A metáfora e a parábola-metáfora não são simples substituições, mas, por sua essência predicativa, criam uma atribuição insólita. Mais ainda, elas são a chave interpretativa para solucionar esta atribuição insólita. Retomamos as próprias palavras de Ricoeur :

O sentido metafórico [...] não é o próprio enigma, a simples colisão semântica, mas a solução do enigma, a instauração da nova pertinência semântica. (Ibid., p. 327-328)

Como pode a metáfora ser solução da nova pertinência semântica? Não apoiando-se sobre as semelhanças como o faria a comparação, mas criando novas similitudes e novas categorias.

Ouçamos novamente Ricoeur: 
O poder da metáfora seria o de romper uma categorização anterior a fim de estabelecer novas fronteiras lógicas sobre as ruínas das precedentes. (Ibid., p. 303)

A metáfora e a parábola estão longe de serem simples comparações. Elas são, ao contrário, dotadas de um grande poder criador, segundo a afirmação de Ricoeur. Sua função é antes de tudo 'dizer e fazer o novo'. Devese concluir que a análise das parábolas que não se colocasse à escuta deste poder criador se enganaria provavelmente sobre a interpretação a ser dada.

Seguindo esta linha, Fraenkel terá justamente como preocupação valorizar constantemente a criação que é o processo parabólico, como veremos nos seguintes capítulos, e o enigma da narrativa, da parábolametáfora, será o coração de sua análise.

\subsubsection{METÁFORA E REALIDADE - METÁFORA E REFERÊNCIA}

Até aqui, vimos a metáfora como enunciado e não somente como palavra isolada, tendo uma função predicativa que vem dizer algo novo, e isto, graças a uma certa impertinência semântica. Esta exposição tratou do que diz a metáfora, ou ainda, de seu sentido.

Uma segunda dimensão deve ser abordada, e devemos perguntar: este sentido diz a respeito de quê? i.e., a que se refere este processo metafórico (a supor que ele se refira a alguma coisa)? Sobre este ponto, tratado especialmente no sétimo estudo da Metáfora Viva, Ricoeur se opõe frontalmente, tanto em sua concepção da metáfora quanto em sua concepção da linguagem em geral, à visão semiótica e estruturalista. Estas duas abordagens fazem das palavras e de suas oposições a unidade mestra, ao passo que Ricoeur opta pela frase e o discurso como unidade de sentido, como já vimos. Mas as conseqüências são consideráveis ao nível da referência. Assim, a primeira abordagem valoriza a linguagem em si e por si mesma. Ricoeur analisa a opinião de Roman Jakobson da seguinte maneira: 
[Roman Jakobson] pretende que a função poética da linguagem consiste no acento posto na linguagem por ela mesma, em detrimento da função referencial da linguagem ordinária. (Id., 2006, p. 174).

Ricoeur critica esta posição que não se interessa senão pelo código e pela estrutura. Para ele, ao contrário, o discurso remete a outra coisa, visa outra coisa, se refere ao mundo. Em outros termos, a metáfora, e com ela a parábola-metáfora, têm algo a dizer sobre a realidade. A parábola não é um simples jogo de linguagem, ou uma ilustração narrativa mais ou menos bem sucedida; ela pretende - no mínimo - dizer algo significativo e carregado de sentido a respeito de alguma coisa que lhe é exterior. A parábola pode então tornar-se parábola hermenêutica:

A hermenêutica não é outra coisa senão a teoria que regula a transição da estrutura da obra ao mundo da obra. Interpretar uma obra é desvendar o mundo ao qual ela se refere em virtude de sua "disposição", de seu "gênero" e de seu "estilo". (Id., 2000, p. 337)

A noção de referência e de hermenêutica é tão capital que constitui a linha divisória na nomenclatura de Jonáh Fraenkel. Ele oporá, com efeito, a parábola retórica à parábola hermenêutica. Ele afirmará em particular que a parábola rabínica é uma parábola hermenêutica, pois ela visa desdobrar o mundo ao qual ela se refere.

A fim de fundamentar o teor e o valor hermenêuticos da metáfora, Ricoeur estabelece um paralelo entre esta e a teoria dos modelos, desenvolvida e aplicada no mundo científico. ${ }^{12}$ Estes modelos são construções fictícias que servem de mediações, de instrumentos teóricos para refutar uma interpretação errônea e propor outras mais adequadas. Eles permitem uma redescrição do real, e esta re-descrição permite não menos que uma descoberta do real. À maneira destes modelos no mundo da ciência, a metáfora e a

\footnotetext{
${ }^{12}$ Ricoeur se apoia, entre outros, sobre os trabalhos de Max Black 'Models and Metaphors' e Mary B. Hesse 'Models and Analogies in Science'.
} 
parábola parecem ter uma função heurística. Somente adentrando nesta função é que se perceberá plenamente o poder de ambas.

Colocando a metáfora no mesmo plano dos modelos científicos, pelo fato de eles terem em comum a capacidade de re-descrição do mundo e de descoberta propriamente dita, Ricoeur confere à metáfora um poder alheio à função da figura de estilo a qual ela foi reduzida durante muito tempo.

\subsection{DA METÁFORA À PARÁBOLA}

Com os trabalhos de Ricoeur, a questão da metáfora passou da palavra para a frase, e se chegou ao conceito de enunciado metafórico. Outra etapa nos resta ainda a galgar para afirmarmos que a narrativa que é a parábola é igualmente um enunciado metafórico, ou ainda, que ela é e atesta um processo metafórico.

Ricoeur aponta que as relações entre as metáforas-enunciado contribuem para a compreensão da metáfora individual. Relações e conexões são criadas para desembocar, de uma certa forma, em uma grande narrativa metafórica. Ouçamos Ricoeur:

Com efeito, uma metáfora nunca aparece só. Uma metáfora chama outra, e todas em conjunto permanecem vivas devido a sua tensão mútua e o poder de cada uma de evocar o conjunto da rede. Por exemplo, na tradição hebraica, Deus é chamado Rei, Pai, Esposo, Dono da casa, Pastor, Juiz e também Rocha, Fortaleza e Redentor, etc. Do mesmo modo, emergem certas metáforas que reúnem muitas metáforas parciais tiradas de diferentes campos de experiência e que lhes fornecem uma espécie de equilíbrio. Essas metáforas "fontes" têm uma aptidão particular a engendrar um número ilimitado de interpretações potenciais em um nível mais conceitual. Assim, ao mesmo tempo reúnem e difundem. Reúnem metáforas subordinadas e difundem novas correntes de pensamento. (Id., 2006, p. 183) 
As metáforas estabelecem então uma espécie de rede. $O$ enunciadoparábola poderia assim inserir-se entre a metáfora como unidade e as metáforas como conjunto mais amplo.

Esta consideração geral que parte da metáfora é completada imediatamente por uma outra que considera a relação entre texto e metáfora:

As narrativas de ficção parecem constituir uma classe à parte no processo metafórico. $\mathrm{O}$ que traz a metáfora não são as frases individuais das narrativas, mas a estrutura inteira, as narrativas tomadas como um todo, o que Aristóteles chamou o mythos no poema. Por conseguinte poderíamos falar da função cênica da parábola [...] Poderíamos dizer, da mesma maneira, que o que trabalha metaforicamente na parábola não é outra coisa do que a narrativa tomada como cênica [...] A tensão produz-se entre a cena e a vida cotidiana e a realidade. (op. cit).

À maneira da metáfora, a cena que é a parábola faz a ponte entre a ficção e a realidade que ela re-descreve. Porém, a tensão, ou mesmo a extravagância, que a parábola introduz em sua trama dramática, produz uma abertura sobre algo além da vida quotidiana. O enunciado parabólico é, também neste sentido, metafórico. 


\title{
1.3 JONÁH FRAENKEL: COMO ABORDAR O MASHAL
}

\subsubsection{DEFINIÇÃO DO MASHAL}

Enquanto Ricoeur define a parábola como a conjunção de uma forma narrativa e um processo metafórico, Jonáh Fraenkel define a parábola rabínica nestes termos:

\begin{abstract}
O termo 'mashal' tem diversos significados na Bíblia, mas na literatura midráshica, tem geralmente um só significado: é a narrativa de uma pequena história fictícia, cujo objetivo é interpretar uma outra coisa, uma coisa que, segundo a opinião do narrador tem necessidade de ser interpretada e é preferível fazê-lo graças a um mashal, e não por si mesma. Esta 'outra coisa' é geralmente chamada 'nimshal'. (FRAENKEL, 1991, p. 323 , tradução nossa). ${ }^{13}$
\end{abstract}

Nesta definição encontram-se elementos de análise da metáfora e da parábola-metáfora desenvolvida por Ricoeur:

- a tônica é posta sobre a narrativa, portanto sobre o discurso portador de sentido predicativo.

- a parábola é uma ficção narrativa. Uma visão historicizante das parábolas é então excluída a priori. Pouco importa, ou mesmo nada, saber se a parábola comporta um núcleo de verdade histórica. A função da parábola não é reportar a um fato real (no sentido de factual).

- A função da parábola é 'interpretar'. O termo volta três vezes na definição de Fraenkel. Ele marca assim com insistência o papel da parábola que ele qualificará de hermenêutico, justamente porque a parábola é destinada a interpretar.

\footnotetext{
למלה "משל" יש במקרא משמעויות שונות אך בספרות המדרשית יש לה בדרך כלל משמעות אחת; סיפור 13

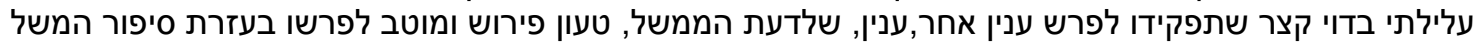

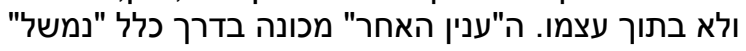


- Ricoeur insiste especialmente sobre a função referencial da metáfora. Esta visa outra coisa que the é exterior. Fraenkel, de forma semelhante, afirma que a parábola é o meio de interpretar esta outra coisa. O objetivo não é a narração da parábola em si mesma, mas sim uma realidade outra. Esta outra coisa é chamada nimshal, i.e., aquilo que é visado pelo mashal, aquilo que é posto em mashal. Este ponto será abordado especificamente no terceiro capítulo.

\subsubsection{O MASHAL COMO MATÉRIA DE ESTUDO ${ }^{14}$}

A definição do mashal proposta por Fraenkel, apoiando-se sobre uma teoria da linguagem e formulada em termos de análise literária, é completada por uma outra formulação do autor:

"Os meshalim dos Sábios de Israel ${ }^{15}$ são, em sua maioria, matéria de estudo, como toda a literatura do midrash e da Torá oral" (Id., 1996, p. 417)

A expressão matéria de estudo que qualifica os meshalim é, em nossa opinião, extremamente pertinente. Ela está com efeito em profunda consonância tanto com os trabalhos de Ricoeur sobre a metáfora quanto com o mundo da literatura rabínica e seus meshalim. Esta expressão pode servir de ponte entre esses dois mundos.

Uma primeira narrativa, o mashal do ladrão de morangos, servirá de base para ilustrar este ponto:

Mashal de alguém que entrou em um pomar, colheu morangos e os comeu.

O proprietário do pomar correu atrás dele

e Ihe disse: "Que tens em tuas mãos?"

Ele Ihe respondeu : « Nada ».

« $E$ no entanto, tuas mãos estão manchadas".

\footnotetext{
חומר לימוד 14

15 'Sábios de Israel': literalmente no acrônimo Hazal, 'os nossos mestres de memória abençoada = חז"
} 
Assim: "A voz do sangue do teu irmão clama a mim a partir da terra". ${ }^{16}$

Este mashal comenta o episódio de Caim e Abel de Gn 4. Caim ataca e mata o seu irmão Abel. A narrativa bíblica prossegue com a pergunta de Deus: 'onde está teu irmão Abel?' a qual Caim responde com outra pergunta: 'sou acaso o guarda do meu irmão?'. Vem em seguida o versículo citado na parábola acima: 'A voz do sangue' etc.

Com relação às metáforas, Ricoeur mostrou quanto o declínio da retórica selou seu destino. Elas não foram mais consideradas senão como simples figuras do discurso tendo um objetivo estético ou persuasivo.

O mesmo destino foi durante muito tempo reservado às parábolas. Este breve mashal do ladrão de morangos traz de maneira pitoresca e trágicocômica o diálogo fictício entre o ladrão e o proprietário do pomar. À pergunta deste último (percebida como uma acusação), o ladrão responde negando categoricamente: 'nada'! (e de fato, suas mãos estão vazias...). Mais tangível a evidência do furto, maior a mentira, parece dizer o mashal. Será que isto ilustraria a insolência da resposta de Caim em Gn 4,10: 'Sou o guarda do meu irmão?', réplica malcriada a qual retruca imediatamente a narrativa bíblica: 'A voz do teu irmão clama até mim...'?

Se a análise da parábola terminasse aqui, há de se constatar que não teríamos nenhuma informação nova sobre o versículo bíblico (e isto contrariamente à teoria de Ricoeur sobre a metáfora). A parábola se reduziria a uma história simples - e até simplista aos olhos de alguns - que somente ilustraria o versículo. Ela poderia talvez ser destinada ao público em geral, às homilias na sinagoga, mas não mereceria provavelmente a atenção como matéria de estudo, pelo fato de ela ser destituída de um teor mais profundo. $\mathrm{E}$, de fato, esta abordagem reducionista da parábola levaria a subestimá-la, da mesma maneira que a metáfora por muito tempo o foi, devido ao declínio da retórica reduzida a uma tropologia. A afirmação de Fraenkel que faz da

\footnotetext{
${ }^{16}$ Midrash Bereshit Rabbá, parashá 22, 9
} 
parábola uma matéria de estudo constitui então um desafio para leitores e ouvintes.

A expressão matéria de estudo está portanto em consonância com os trabalhos de Ricoeur, e encontra também semelhante consonância nos dizeres dos Sábios da literatura rabínica. Estes, com efeito, ao seu modo, advertiram os ouvintes para não receberem os meshalim de maneira reducionista. Escutemos o mashal do pavio:

Nossos mestres dizem:

que o mashal não seja considerado fácil aos teus olhos, pois graças a este mashal, pode-se compreender as palavras da Torá.

Mashal de um rei que havia perdido uma moeda de ouro ou uma pérola preciosa, dentro de sua casa.

Não é graças a um pavio de ínfimo valor que ele a encontra?

Assim, que o mashal não seja considerado fácil aos teus olhos, pois é graças ao mashal que se compreende as palavras da Torá. $^{17}$

Os Sábios querem evitar a desvalorização do mashal por parte daqueles que estudam a Torá. Este ensinamento faz subentender então que existia esta tendência: o mashal parecia ser provavelmente de segunda categoria, comparado às questões essenciais de Halakhá, i.e., de prática dos mandamentos, por exemplo. Paradoxalmente, os Sábios reconhecem e afirmam que o mashal não possui nenhum valor intrínseco: ele é, aparentemente, como um pavio que se joga fora após ter sido utilizado. Porém, é graças a este pavio que o leitor caminhará até encontrar a peça de ouro, a pérola perdida na escuridão. É o mashal que permitirá descobrir e desvelar as palavras da Torá. Seu papel exegético e hermenêutico vai muito além da aparente banalidade dos termos utilizados e das histórias colocadas em cena. A parábola do ladrão de morangos, por exemplo, narrativa decerto pitoresca, porém aparentemente banal, não mostrou ainda a pérola do versículo que ela

\footnotetext{
${ }^{17}$ Shir haShirim Rabá, 1,1
} 
interpreta (e não somente ilustra). Ela ainda não se tornou matéria de estudo. Seguindo os passos metodológicos de Fraenkel, veremos nos dois próximos capítulos como abordá-la nesta perspectiva.

A expressão matéria de estudo é igualmente a oportunidade de se interrogar acerca do meio no qual surgem as parábolas. Pensa-se muitas vezes que estas histórias simples seriam somente destinadas a uma simples pregação, para um auditório simples. A realidade do surgimento das parábolas é bem outra. Elas se inserem na corrente da intensa elaboração da literatura mishnáica e talmúdica, tanto nos centros de estudos em Israel quanto na Babilônia. O Beit Midrash, a casa de estudos, é o terreno fértil das parábolas, independentemente de um auditório mais amplo. Elas são o fruto deste estudo, e por isso, tornam-se matéria de estudo. Sua formulação simples e atraente Ihes permite atingir toda e qualquer pessoa, mas isso não tira nada de sua complexidade e finura: 'que o mashal não seja considerado fácil aos teus olhos', repetem os Sábios.

O mashal rabínico sendo uma matéria de estudo, convém abordálo segundo a análise e a metodologia que melhor permitirão adentrá-lo. A fim de balizar esta análise, Fraenkel propõe várias etapas:

\footnotetext{
$\checkmark$ a definição do 'modelo de base' da parábola

$\checkmark$ a análise da parábola como narrativa de gênero dramático

$\checkmark$ a comparação entre o mashal e o nimshal, i.e., aquilo que está sendo colocado em parábola

$\checkmark$ o desvelamento, a novidade ensinada pela parábola
}

Estas etapas se inspiram, direta ou indiretamente, nos trabalhos de Paul Ricoeur sobre a metáfora e a narrativa. Exporemos estas etapas, ilustrando-as nos capítulos seguintes com as cinco parábolas escolhidas. 


\section{CAPÍTULO II}

\section{A ANÁLISE DO MASHAL: \\ MODELO DE BASE E NARRATIVA}

\subsection{DISTINÇÃO MASHAL, NIMSHAL, DERASHÁ}

A função essencial do mashal é comentar a Torá, tanto escrita como oral, ou ilustrar um comentário a seu respeito. O mashal raramente aparece isolado: ele será inserido na maioria das vezes em uma composição literária na qual convém distinguir vários elementos. De maneira ideal, encontram-se nela quatro elementos:

- um versículo bíblico ou um dito de um sábio

- um comentário sobre esse versículo ou esse dito: é a derashá (comentário)

- a parábola, o mashal

- o nimshal

Eis a seguir um exemplo de inserção de parábola em uma composição talmúdica ${ }^{18}$, o 'mashal das vestes reais'.

Os nossos mestres ensinaram:

"O sopro volta a Deus que o deu" (Qohelet 12,7).

Devolve-o a ele como ele o deu a ti: ele o deu a ti puro, devolve-o a ele puro.

Parábola de um rei humano que distribui vestes reais aos seus servos. Aqueles dentre eles que eram sensatos as dobraram e as colocaram em um cofre.

\footnotetext{
${ }^{18}$ Talmud da Babilônia, Tratado Shabat, folha 152b.
} 
Aqueles dentre eles que eram insensatos as vestiram para ir ao trabalho. Algum tempo depois, o rei pediu as suas vestes.

Os sensatos as devolveram a ele impecáveis.

Os insensatos as devolveram a ele completamente sujas.

$O$ rei se alegrou com os sensatos e se encolerizou vendo os insensatos.

A respeito dos sensatos, ele disse:

que minhas vestes sejam colocadas no tesouro e que estes possam ir para suas casas em paz.

A respeito dos insensatos ele disse:

que minhas vestes sejam entregues aos lavadeiros e que esses sejam jogados na prisão.

Assim o Santo-Bendito-Seja-Ele disse a respeito do corpo dos justos:

"Mas virá a paz, e estarão em repouso, em seus leitos" (Is 57,2)

e a respeito de sua alma, a Escritura diz:

"Mas a vida de meu senhor permanecerá guardada no bornal dos vivos junto do Senhor, teu Deus" (1Sm 25,29).

Mas a respeito do corpo dos maus, a Escritura diz:

"Mas para os maus não há paz, diz o Senhor" (Is 48,22),

e a respeito de sua alma: "A vida de teus inimigos, o Senhor a arremessará para longe, da cavidade de sua funda" (1Sm 25,29).

Após a fórmula introdutória 'os nossos mestres ensinaram', é citado o versículo de Qohelet. Em seguida, os sábios dão a sua interpretação do versículo. Os sábios não se contentam com o sentido óbvio da Escritura, o peshat, mas cavam o versículo para descobrir nele outros sentidos. Eles podem assim afirmar que o sopro não volta a Deus de maneira natural e, por assim dizer, automática (o que o versículo insinua). Trata-se, ao contrário, de entregar este sopro. O comentário interpretativo, a derashá, utiliza então o verbo devolver e não voltar como o fez o versículo. ${ }^{19} \mathrm{O}$ ser humano tem então sua parte ativa neste processo. Constata-se com isto que a concepção da morte de Hazal difere daquela dos autores bíblicos.

Além disso, a derashá indica em quais condições deve ser feita essa devolução: em estado de pureza. Esta idéia é ausente no versículo. Neste

\footnotetext{
${ }^{19}$ Notemos que é a passagem do qal de לשוב para o hif'il להשיב. Porém a derashá não explorou esse possível jogo sobre as modalidades da raiz verbal שוב, tendo empregado o verbo לתת.
} 
breve comentário (apenas nove palavras no hebraico!) pode-se ver o quanto os Sábios escrutaram com peculiar atenção o versículo, para que surjam novos sentidos. Esta é a função da derashá, esse perscrutar, essa busca constante que produz a Torá oral.

Após o comentário foi inserida a parábola, que começa com 'palavra de um rei humano' e vai até 'que esses sejam jogados na prisão'. Essa parábola ilustra, a priori, o comentário. Veremos a partir do ponto 2.2 e o modelo de base como analisá-la, mas podemos já indicar que a introdução do personagem humano rei permite facilmente a passagem do registro humano ao divino; i.e., Israel face a seu Deus. Esta passagem é o movimento do mashal para o nimshal. Este começa com a expressão 'Assim o Santo-Bendito-SejaEle...' e vai até o fim deste trecho.

O que é o nimshal? "Uma coisa ou uma idéia que serve de fundamento ou de base ao mashal; moral que emerge do mashal" nos diz Even-Shoshan. ${ }^{20}$ Esta definição e os termos de nossas línguas latinas (a parábola e sua máxima, sua moral, etc.) não refletem, contudo, o liame que aparece imediatamente em hebraico, pela prefixação da letra nun ao termo mashal. ${ }^{21}$ Passa-se então de um substantivo elaborado sobre um padrão qal, ao seu correspondente sobre o padrão nif'al. Em outras palavras, passa-se de um aspecto ativo (o mashal que é a narrativa) ao seu correspondente reflexivo-passivo: o nimshal, o que é colocado em parábola, o que é 'parabolisado'.

\subsection{O MODELO DE BASE}

Segundo Fraenkel, a análise do mashal rabínico deve começar por determinar seu 'modelo de base, ${ }^{22}$, o molde que constitui a sua principal armação, ou ainda o núcleo ao redor do qual se desenvolve o mashal. Trata-se em um primeiro tempo de considerar as personagens principais e suas características, bem como as relações entre estas personagens.

\footnotetext{
${ }^{20}$ Cf. verbete נמשל in: EVEN-SHOSHAN (1987).

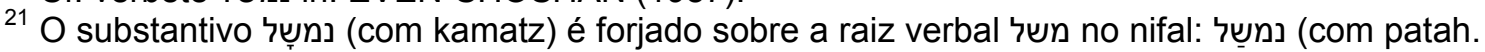
Segundo Even-Shoshan, o substantivo pertence ao estrato da língua da Idade Média (comentários e literatura rabínica).

${ }^{22}$ A expressão utilizada por Fraenkel é דגם היסוד. Não se trata contudo dos modelos dos quais falamos no capítulo 1 .
} 


\subsubsection{VARIEDADE DOS MODELOS DE BASE}

Os modelos de base que se encontram nas parábolas de Hazal são muito variados. O mais conhecido e difundido é sem dúvida aquele do rei e seus servos, já encontrado no trecho do Talmud da Babilônia, Shabat, 152b. Isto não é surpreendente considerando que a realidade visada pelos Sábios de Israel seja uma realidade religiosa e espiritual que trata de Deus, de Israel, da humanidade em geral, e das relações entre estes conjuntos. O modelo do rei e dos servos impõe-se naturalmente.

Porém, múltiplas variações são possíveis. Eis algumas:

- o rei e seu filho ou seus filhos

- o rei que se reconcilia com sua esposa

- o rei que casa sua filha

- o rei e seu amigo

- o rei e seus generais

- o rei organiza um banquete

- o rei emprega operários

- o rei confronta-se com brigantes, etc.

As situações criadas são diversificadas, mas muitas dentre elas giram em torno de um conflito que convém resolver se possível. O rei pode, por exemplo, ameaçar seu filho ou mesmo lhe bater. Assim fazendo, ele provoca a reação do seu amigo presente, ou ainda educará seu filho mostrando-lhe a utilidade de um curativo (a Torá...). O rei pode igualmente ter uma atitude mais radical e, após bater em seus filhos, os enviar um após outro ao exílio, reconhecendo ao mesmo tempo sua responsabilidade: 'eu Ihes dei uma má educação'. Mais radical ainda, um pouco adiante na mesma passagem, este rei encolerizado desferirá golpes tais em seus filhos que estes morrerão (Eikha Raba 1,16). Diferentemente, um outro mashal mostra que este desejo de matar seu filho pode ser impedido pela intervenção de sua esposa, que, cada vez, consegue salvar seu filho da terrível mão do pai, como Moisés salva o povo de Israel da cólera de Deus. 
Outros modelos colocando em cena um rei são menos dramáticos e utilizam fatos da vida quotidiana: um presente feito ao seu filho, pratos confeccionados pelos cozinheiros, roupas passadas pelos seus servos ou ainda o divórcio de sua esposa. Outros enfim tratam do governo do reino, das relações com os responsáveis dos exércitos, com os súditos, ou ainda da vida econômica e das obrigações que ela implica: o salário que deve ser pago aos operários contratados, por exemplo.

O modelo de base colocando em cena um rei é o modelo por excelência das parábolas dos Sábios de Israel, mas muitos outros modelos são possíveis, com outras personagens e situações. Citemos, a título de exemplo:

- o oleiro que verifica a resistência dos seus vasos de argila (Bereshit Rabá 32,3)

- alguém sofre de uma ferida ou de uma fratura e se aconselha com um médico (TB Moed Katan 21b e Tosefta Shkalim 1,6)

- os perigos do caminho no qual o peregrino encontra um lobo, um leão e uma serpente (Tosefta Berakhot 1,10)

- a árvore com ramos desenvolvidos e raízes pouco profundas. (Mishná Tratado Avot 3,17)

Enfim, o modelo mais freqüente nas fábulas de outras culturas - as fábulas de Esopo, por exemplo - não está ausente na literatura de Hazal. Trata-se de parábolas que colocam em cena animais falando e agindo como humanos: uma raposa jejua para poder passar através da barreira que circunda uma apetitosa vinha (Qohelet Raba 5,14). Outra raposa convida peixes que logo vão ser capturados pelos pescadores para juntar-se a ela em terra firme: é uma das cinco parábolas escolhidas para este estudo (TB, Berakhot $61, b$ ) ou ainda, um galo e um morcego que esperam a aurora (TB Sanhedrin 78b).

\subsubsection{ANÁLISE DO MODELO DE BASE}


A fim de melhor entender a utilização do modelo de base pelo autor de um mashal, Fraenkel propõe uma análise deste em três pontos: (FRAENKEL, 1996, p. 412)

1. estabelecer o conteúdo do modelo

2. estabelecer a ou as razões pelas quais o autor escolheu este modelo

3. perguntar-se por que o autor renunciou a outros modelos

\subsubsection{MASHAL DO ARRENDATÁRIO}

Tomemos um primeiro exemplo, para analisarmos o modelo de base.

"Ao fim de certo tempo, Caim trouxe frutos da terra, uma oferenda ao Senhor" (Gn 4,3).

Frutos avariados.

Parábola de um arrendatário mau

que comia as primícias

e entregava ao rei os derradeiros. ${ }^{23}$

Antes de tudo, convém distinguir com clareza as três partes que constituem este pequeno texto:

- a citação de um versículo

- o comentário do versículo: a oferenda é constituída por 'frutos avariados'

- o mashal (sem nimshal explícito).

Concentraremo-nos por enquanto unicamente na parábola. Ela apresenta duas personagens: um rei-proprietário e um arrendatário. As relações entre eles são estabelecidas por um contrato: o proprietário aluga a sua terra ao arrendatário que, em guisa de pagamento, deve lhe fornecer uma parte da colheita, como estabelecido entre as duas partes. $O$ autor escolheu este modelo exatamente em razão da obrigação que liga o arrendatário ao proprietário: os frutos trazidos não são em nada uma oferenda, termo utilizado pelo versículo bíblico, ou um dom do arrendatário, mas sim um dever que faz parte do contrato. A mera escolha deste modelo de base faz com que o mashal

${ }^{23}$ Midrash Bereshit Rabá, Parashá 22, 5. 
possa questionar então - e reinterpretar - o versículo bíblico a respeito da palavra oferenda entendida como obrigação que o arrendatário Caim deve cumprir.

O autor do mashal renunciou a outros modelos que apresentariam relações diferentes entre os personagens. Se a terra fosse dada como presente, os frutos trazidos seriam de fato uma oferenda voluntária e livre da parte daquele que os colheu. Esta oferenda seria um sinal de seu reconhecimento pelo dom recebido. Mas, interpretar nossa parábola nesses termos de reconhecimento e de gratidão - o que o termo oferenda do versículo bíblico convida quase naturalmente a fazer - levaria a um engano: o modelo de base escolhido livremente pelo autor proíbe uma tal interpretação, inserindo a história no quadro preciso das relações entre um arrendatário e um proprietário. Estas são regidas em primeiro lugar por deveres e obrigações, e não por sentimentos de reconhecimento.

O modelo de base escolhido aqui determina então de maneira muito precisa a análise da parábola. Ele reflete também a concepção do mundo do autor, segundo o qual a humanidade não é proprietária do mundo. Portanto, ela deve prestar contas da sua utilização ao seu criador.

\subsubsection{MASHAL DA JARRA D'ÁGUA}

Um outro exemplo nos mostrará o quanto o modelo de base é uma baliza importante para analisar o mashal.

Durante os sete dias [da Festa das Tendas],

o homem deve fazer de sua Tenda sua habitação principal

e de sua casa uma morada provisória.

Se cair a chuva, a partir de qual momento

é permitido deixar [a tenda]?

Quando um prato de mingau se estragar [por causa da chuva].

Conta-se esta parábola: a que isto pode ser comparado?

A um servo que veio encher a taça do seu senhor, ele [o senhor] virou a jarra na sua cara. ${ }^{24}$

\footnotetext{
${ }^{24}$ Mishná Suká 2,9.
} 
A breve parábola ao final desta narrativa é elaborada sobre o modelo do senhor e do seu servo. Este modelo determina de maneira precisa características dos dois personagens. Um é livre de agir ao seu bel prazer, o outro permanece sob a total dependência do seu senhor. Notemos que o servo não faz senão o seu dever trazendo a bebida ao seu mestre (que provavelmente the ordenou). A atitude - ou mais exatamente a reação - do senhor que humilha seu servo é decerto estranha à primeira vista, mas ela é perfeitamente permitida no quadro deste modelo de base escolhido pelo autor. Considerar esta atitude injusta ou indigna não respeitaria a escolha deliberada deste modelo. É, portanto, a base a partir da qual e na qual convém analisar esta narrativa.

\subsubsection{MODELOS DE BASE, ESQUEMATIZAÇÃO, TRADICIONALIDADE (RICOEUR)}

A noção de modelo de base utilizada por Fraenkel em sua análise das parábolas pode encontrar sua origem teórica e seu paralelo nos trabalhos de Ricoeur sobre a metáfora e a narrativa em geral, com as noções de esquematização e de tradicionalidade. Ricoeur precisa essas duas noções no capítulo de Tempo e Narrativa tratando da mîmesis e do ato configurante:

Numa ótica ainda kantiana, não se deve hesitar em aproximar a produção do ato configurante do trabalho da imaginação produtora [...] A imaginação não só não é sem regra, mas constitui a matriz geradora das regras. Na primeira Crítica, as categorias do entendimento são primeiro esquematizadas pela imaginação produtora. O esquematismo tem esse poder, porque a imaginação produtora tem fundamentalmente uma função sintética. Ela liga o entendimento e a intuição, engendrando sínteses ao mesmo tempo intelectuais e intuitivas. A tessitura da intriga igualmente engendra uma inteligibilidade mista entre 0 que já se chamou de a ponta, o tema, o "pensamento" da história narrada e a apresentação intuitiva das circunstâncias, dos caracteres, dos episódios e das mudanças de fortuna que produzem o desenlace. É assim que se pode falar de um esquematismo da função narrativa. (RICOEUR, 1994, p. 107) 
Ricoeur prossegue :

Este esquematismo, por sua vez, constitui-se em uma história que tem todas as características de uma tradição. Entendemos por isso não a transmissão inerte de um depósito já morto, mas a transmissão viva de uma inovação sempre suscetível de ser reativada por um retorno aos momentos mais criadores do fazer poético $[\ldots]$

A constituição de uma tradição, com efeito, repousa sobre o jogo da inovação e da sedimentação. É à sedimentação, para começar por ela, que devem ser relacionados os paradigmas que constituem a tipologia da tessitura da intriga. (op. cit.)

Ricoeur expõe aqui de maneira teórica várias noções parentes: esquematização, sedimentação, tradicionalidade - que Fraenkel traduzirá e aplicará na noção e instrumento de análise que são os 'modelos de base'. Eles constituem a matriz das parábolas e facilitam sua inteligibilidade, indicando, a priori, certas regras de compreensão: as funções e as relações dos personagens são, com efeito, balizas imprescindíveis para adentrar uma parábola. Podemos aplicar-Ihes o que Ricoeur diz dos paradigmas:

Ora, esses paradigmas, eles próprios oriundos de uma inovação anterior, fornecem regras para uma experimentação ulterior no campo narrativo. Essas regras mudam, pressionadas por novas invenções, mas mudam lentamente e até resistem à mudança, em virtude do próprio processo de sedimentação. (Ibid., p. 1089)

Notemos ainda que esta sedimentação, i.e., esta lenta elaboração dos paradigmas, dos modelos de base é o fruto do beit hamidrash, da casa de estudos dos sábios e de seus discípulos, onde são elaboradas, utilizadas, lapidadas, modificadas essas matrizes. Os modelos de base, e as parábolas em geral, são certamente o resultado de uma complexa composição literária, e não composições mais ou menos improvisadas diante de um auditório.

Aliás, esta não-improvisação e o emprego de modelo de base permitem uma inteligibilidade primeira do auditório. Com efeito, as regras essenciais de 
análise são postas desde as primeiras palavras: 'mashal de um rei e de seus servos...'. A esquematização permite uma concisão muito apreciada. Não há necessidade alguma de longa introdução. $O$ auditório pode ao contrário ter a impressão de entrar diretamente nessas narrativas. Esta conciliação entre o refinamento literário no beit hamidrash e a recepção popular fora dele constitui um precioso trunfo para as parábolas.

\subsubsection{MODELOS DE BASE VS DIVERSIDADE DAS REALIDADES RELIGIOSAS}

Vimos que o modelo de base mais difundido é aquele do rei e de seus servos. Isto não é surpreendente, pois a literatura de Hazal trata em primeiro lugar da relação de Israel com Deus. Contudo, este modelo não é nada fixo. Mas, ao contrário, os autores introduzem nele inúmeras modificações e adaptações. Esta diversidade tem por objetivo apontar diversas atitudes e situações religiosas que o modelo rei / servo deve refletir. Existem outros modelos que permitem ser, igualmente, espelhos e instrumentos da reflexão sobre a vida e a fé do povo de Israel.

Esses modelos têm então a vantagem de constituir um rico estoque sempre ao alcance dos autores, permanecendo, contudo, sempre maleáveis. Nada impede, aliás, que a criatividade dos autores elabore novos modelos que integrarão o estoque comum.

\subsection{O MASHAL COMO NARRATIVA}

\subsubsection{A PARÁBOLA COMO NARRATIVA (RICOEUR)}

No primeiro capítulo, vimos que Ricoeur, no tratamento da metáfora, opera um deslocamento da palavra (a metáfora-tropo) à frase, e depois, da 
frase ao enunciado, qualificado de enunciado metafórico. Este enunciado toma a forma de uma narrativa nas parábolas de Hazal. Nosso autor desenvolve várias linhas de reflexão sobre a noção de enunciado e de narrativa, noções que sustentam a análise e o método de Fraenkel com relação às parábolas.

Ricoeur insiste particularmente sobre a noção de discurso e nos lembra que:

a fonte da noção do texto é a de 'discurso'. Entendo por 'discurso' a atualização da linguagem em um ato de palavra baseado em um gênero de unidade irredutível aos elementos constitutivos da linguagem como código. Essa unidade de base da linguagem é a frase" (Id., 2006, p. 162)

Longe de ser um mero código, todo discurso é um ato de fala que envolve um mundo extra-lingüístico, um locutor, um destinatário. No caso das parábolas rabínicas, este aspecto permanece particularmente vivo, pois elas são enquadradas facilmente em seu Sitz-im-Leben e no beit midrash de onde, em sua maioria, são oriundas. O caráter oral - ao menos em um primeiro tempo - desta literatura mantém viva a percepção do ato de fala que é a parábola.

Ricoeur aponta igualmente o discurso (e portanto a narrativa) como uma obra (uma obra de arte), a palavra 'obra' sendo entendida no seu sentido etimológico de produção e de trabalho (Ibid., p. 164). Este processo requer uma composição e uma codificação segundo as regras próprias do discurso; ele requer um modelar da linguagem para produzir esta obra. A estes gêneros pertencem os gêneros literários, inclusive a narrativa, que são "um meio para produzir mensagens singulares, para dar um estilo a discursos individuais" (op. cit.). Esta afirmação encontra sua expressão na imensa rede de parábolas de Hazal, onde cada narrativa, cada parábola é única, produzindo uma mensagem única, da qual ela é portadora.

Ricoeur traz outra face à questão da narrativa, insistindo sobre seu aspecto comunicacional. $O$ ato de fala que é a parábola é um ato de comunicação entre interlocutores, que vem criar e comunicar - e isto especificamente enquanto parábolas - uma abertura sobre o mundo: a 
comunicação narrativa « abre para o mundo, a saber para uma situação e uma experiência humanas que recebem um novo poder de interpretação da dimensão mimética da narrativa » (Ibid., p. 167-8).

\subsubsection{O MASHAL COMO NARRATIVA (FRAENKEL)}

A definição do mashal por Fraenkel, citada no capítulo 1 deste estudo (1.2.1) comporta a expressão 'narrativa de uma pequena história fictícia'. Nosso autor considera então o gênero literário narrativo como componente essencial da parábola. Assim, ele segue a via traçada por Ricoeur, como acabamos de ver.

Fraenkel completa sua definição do mashal, insistindo sobre o aspecto literário que nos interessa aqui. Para isto, ele se apóia sobre os recentes trabalhos concernentes às parábolas dos Evangelhos:

As parábolas são criações literárias, breves mas completas, que apresentam um assunto literário e humano completo. Por isso é necessário interpretar a trama da parábola como qualquer trama numa composição artística literária. O estilo das parábolas de Hazal se caracteriza evidentemente por seu aspecto dramático quanto ao seu essencial, isto significa que a ação comporta tensões, mas não apresenta descrição da realidade, ou desenvolvimentos épicos. (FRAENKEL, 1991, p. 332, tradução nossa). ${ }^{25}$

Vimos acima (2.1) a distinção entre versículo, comentário (derashá), mashal e nimshal, a fim de identificar e de isolar a parábola enquanto tal. $A$ presente definição de mashal indica que esta é uma 'criação completa', apresentando um assunto 'completo'. Segundo Fraenkel, é necessário então, em um primeiro tempo, analisar a parábola como unidade isolada, independentemente do seu contexto literário (versículo, comentário, nimshal).

\footnotetext{
"המשלים הם יצירות ספרותיות, קטנות אבל שלמות, המצייגות עניין ספרותי-אנושי שלם ולכן יש להבין אילין את 25

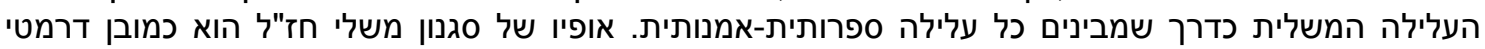
בעיקרו, כלומר יש בעלילה מתחים ואין בו תיאורים ריאליים- אפיים רחבים דים דילים
} 
Se esta unidade é considerada como 'completa', deve-se então interpretá-la por si mesma e em si mesma.

A definição de Fraenkel nos lembra que a parábola não é uma descrição da realidade, à maneira de uma narrativa historiográfica, mas uma ficção a serviço de uma realidade humana. Os detalhes de cunho real passam então ao segundo plano e serão até mesmo totalmente ignorados na análise da parábola. A veracidade histórica de um acontecimento relatado nas parábolas é de pouca importância.

Fraenkel acrescenta que a parábola pertence ao gênero dramático. Este gênero, diferentemente daqueles épicos e líricos, caracteriza-se por uma 'desordem', um 'desequilíbrio' no interior de uma certa ordem (PIRES, 1989, p. 167-172). A palavra-mestra aqui é tensão. O mashal se desenvolve em função desta tensão e cada detalhe, cada palavra, cada gesto das personagens vêm aumentar a tensão que desemboca freqüentemente em um conflito. Tudo, na narrativa, é alusão e intenção para formar a intriga do drama. Convém então interrogar sobre a escolha que o autor fez de tal ou tal palavra, sobre o liame entre as etapas que conduzem à crise-conflito, sobre as questões que as personagens podem ou devem levantar. A elas cabe, com efeito, compreender a situação - compreender o mundo que as circunda - e de fazer escolhas para tentar resolver a crise. O papel das personagens, e por esse viés aquele do auditório, é essencial em toda a narrativa da parábola, pois essas personagens têm a chave do desfecho. Citemos o que diz Pires a propósito do drama, e que pode se aplicar igualmente, de uma certa maneira, às parábolas:

Durante o desenrolar da peça o Homem tem a liberdade de escolha entre a insurreição ou a resignação. O herói do drama é necessariamente ativo; um Herói passivo não é dramático" (lbid., p. 171)

As personagens das parábolas de Hazal são todas confrontadas com esta liberdade de escolha, pois ela faz parte integrante da concepção do seu mundo. 


\subsubsection{EXEMPLOS DE ANÁLISE DE NARRATIVA}

\subsubsection{MASHAL DO LADRÃO DE MORANGOS (cf texto: 1.3.2)}

Este breve mashal é construído sobre o modelo do proprietário que corre atrás de um ladrão para prendê-lo. Notemos que o autor coloca em cena o proprietário do pomar, e não um guarda qualquer. Não teria este detalhe importância ao longo do mashal?

A narrativa começa por constatar simplesmente o furto dos frutos, mas observemos que nenhuma palavra é dita sobre o motivo deste furto. Isto não interessa aparentemente ao autor da parábola.

O segundo elemento colocado em cena aqui é aquele da reação do proprietário, que 'correu atrás dele'. A respeito deste novo elemento que aumenta a tensão da narrativa, o auditório poderia perguntar sobre o motivo desta corrida atrás do ladrão:

a) talvez o proprietário não tenha apanhado o ladrão em flagrante; ele apenas o viu em sua propriedade, e supôs que tenha havido furto. Pegando o intruso - que não é ainda comprovadamente um ladrão -, ele quer verificar o que aconteceu.

b) ao constatar o furto, ele corre atrás do ladrão para recuperar seu bem e/ou levar a pessoa diante de um tribunal.

Fraenkel considera a parábola como uma unidade completa em si. A resposta à suposta questão dos ouvintes deveria então ser encontrada na própria parábola. Ela aparece de fato pelo viés da pergunta do proprietário: 'que tens em tuas mãos?', o que permite supor que o proprietário tem certeza do furto. Contudo, observemos que o autor não escolheu colocar na boca do proprietário uma acusação contra o ladrão, do tipo: 'eu te vi furtando meus morangos!' A escolha do autor é de grande importância, pois ele situa a ação do proprietário entre dois pólos, entre os quais a sua questão estabelece esta tensão: o proprietário sabe que o intruso furtou, porém, ele não o acusa desde 
o início. Somente com a última frase do mashal a evidência vem às claras: 'e no entanto, tuas mãos estão manchadas'.

Notemos enfim uma aparente contradição entre as duas falas do proprietário: 'que tens em tuas mãos?' ( = tens alguma coisa em tuas mãos) e a afirmação 'tuas mãos estão manchadas' onde não é dito que as mãos (mostradas pelo acusado) contenham alguma coisa, mas sim que elas foram manchadas por alguma coisa. Essas aparentes incoerências da parábola são importantes, pois assinalam os limites de uma interpretação que permaneceriam somente no quadro restrito da narrativa. Esta "unidade completa em si", segundo os dizeres de Fraenkel, não é suficientemente completa para ser analisada de maneira satisfatória. Ela requer de fato uma etapa suplementar que consistirá na colocação em paralelo do mashal e do nimshal, a etapa seguinte na análise que propõe o nosso autor.

\subsubsection{MASHAL DAS VESTES REAIS (cf texto: 2.1)}

Este texto foi citado no início deste capítulo para colocar em evidência os elementos possíveis de uma composição rabínica em torno de um mashal, a saber, o versículo, seu comentário, o mashal propriamente dito e o nimshal. Por enquanto, analisaremos somente a parábola, como unidade narrativa em si, fazendo voluntariamente abstração dos três outros elementos.

O modelo de base é aquele de um rei e seus servos. A primeira frase é de primordial importância: este rei humano distribui vestes reais a seus servos. Este gesto é certamente insólito e inesperado. Mas o modelo de base escolhido pelo autor nos convida a não prestar atenção a estas interrogações. Este modelo estabelece, com efeito, que o rei pode agir como quiser para com seus servos. Ele pode se permitir toda e qualquer generosidade.

Fraenkel insiste sobre a rede de detalhes que contribuem para a tensão de um texto, e podemos verificar que nesta parábola, nenhum dentre eles é supérfluo. O verbo distribuiu merece aqui toda a atenção dos ouvintes: qual é o seu sentido exato? Quais são o motivo e o objetivo desta distribuição? 
Ademais, por que empregar o verbo distribuir e não o verbo doar? Talvez o rei não tivesse doado a seus servos estas vestes reais?

A etapa seguinte da narrativa é constituída pelas atitudes que o gesto do rei desperta nos servos: alguns 'as dobraram e as colocaram em um cofre', ao passo que outros 'as vestiram para ir ao trabalho'. Notemos contudo que os primeiros são qualificados de sensatos ao passo que os outros são insensatos. Estes dois qualificativos atenuam a tensão da narrativa pois fornecem já ao auditório uma chave de interpretação. Pode-se logicamente supor que estes dois qualificativos não figuravam em uma versão destinada a despertar a atenção e a curiosidade dos ouvintes. Cabe-lhes de fato determinar quem são os sensatos e quem são os insensatos.

A tensão criada ao início da narrativa encontra seu apogeu com a crise que eclode quando 'o rei pediu as suas vestes'. A afirmação de Fraenkel da parábola como unidade completa se verifica aqui a respeito do seguinte ponto: o verbo distribuir encontra sua explicação na própria parábola. Se o autor escolheu com cuidado e propositalmente este verbo, é exatamente para dizer que o rei não fez dom das vestes reais. Estas continuam pertencendo ao rei. Por isso, aliás, o seu gesto parece ainda mais estranho e insólito.

A etapa seguinte descreve o desfecho da crise: as duas atitudes dos servos são julgadas pelo rei. Os primeiros suscitam sua alegria, as vestes encontram o seu lugar no baú (tesouro) e os servos usufruem da paz em suas casas. Os segundos despertam a cólera do rei, as vestes são lavadas e os servos jogados na prisão. Este desfecho da crise suscita mais interrogações do que resolve: estes servos merecem ser jogados na prisão sendo que eles continuaram a fazer seu dever que é trabalhar? Qual era então a intenção do rei ao distribuir as vestes reais?

Mais uma vez, a parábola carece de elementos que lhe sejam exteriores para ser interpretada na perspectiva de Hazal.

2.3.3.3 MASHAL DA JARRA D’ÁGUA (cf texto: 2.2.2.2 ) 
Este brevíssimo mashal é igualmente composto sobre o modelo de base rei (ou senhor), modelo que implica uma relação de dependência total do servo para com o rei.

A trama é constituída por uma ação do servo que age segundo sua função e seu dever, versando um líquido na taça do seu senhor. A reação totalmente inesperada do mestre que derrama o líquido sobre a cabeça do seu servo constitui o paroxismo da crise. Notemos que a parábola não oferece nenhuma solução para abrandar esta tensão, nenhum desfecho a esta crise. Ela deixa tudo suspenso.

Se é impossível, a partir da mera narrativa, compreender plenamente a intenção do rei, pode-se ao menos afirmar que ele deseja humilhar seu servo publicamente, e que e o conseguiu perfeitamente. Isto só reforça as indagações acerca do sentido desta parábola.

\subsubsection{MASHAL DA RAPOSA E DOS PEIXES}

Introduziremos aqui uma parábola assaz conhecida, extraída do Talmud da Babilônia. Ela é narrada como proveniente do próprio Rabi Aqiva.

Papos ben Yehudá foi visitar Rabi Aqiva

e o encontrou sentado interpretando [a Torá],

fazendo assembléias públicas,

e com um livro da Torá em seu colo.

Papos lhe disse:

"Aqiva, não tens medo deste governo [romano]?"

Ele respondeu-Ihe:

"Não és tu Papos ben Yehudá,

do qual dizem ser um grande sábio?

Não passas de um tolo.

Vou contar-te uma parábola: a que isto é semelhante?

A uma raposa que caminhava à margem de um lago e que via peixes se juntando [em um lugar].

Ela lhes disse:

Por que vós vos juntais [em um lugar]? 
Eles Ihe disseram:

por causa das redes e das armadilhas que fazem os humanos para prender-nos.

Ela lhes disse:

Subí para a terra seca e moraremos juntos, eu e vós, como moravam meus pais e os vossos pais.

Eles Ihe disseram:

Tu és a raposa da qual dizem ser a mais matreira de todos os animais? Não passas de uma estúpida!

Se agora que estamos no nosso lugar vital é assim, pior será se subirmos para a terra seca, lugar da nossa morte!

Também para ti é assim: se agora que nos ocupamos com a Torá, da qual a Escritura diz (Dt 30,20):

"Porque ele [sic] é tua vida e o prolongamento de teus dias", e [se a situação é] assim, pior será se nós a abandonarmos!

Conta-se que poucos dias depois, Aqiva foi detido e acorrentado na prisão.

Papos também foi preso e acorrentado perto de ele.

Rabi Aqiva Ihe disse:

"Papos, por que te trouxeram aqui?"

Este Ihe respondeu:

"Feliz és tu, Aqiva, que foste preso por causa das palavras da Torá! Infeliz Papos que foi preso por causa de coisas vãs!" 26

O modelo de base desta parábola é constituído por vários atuantes:

- a raposa que tem a reputação de ser um animal matreiro, à espreita de suas presas,

- peixes que parecem destinados a ser a presa, tanto da raposa quanto dos homens,

- homens que fazem redes para capturar os peixes. Esta relação de captura entre homens e peixes existiu sempre e sempre existirá. A única saída possível para os peixes é de manter-se agrupados em um lugar pouco acessível ou de fugir de um lugar para outro.

- o quarto elemento em torno do qual é construída a parábola é aquele da água. Esta, evidentemente, é absolutamente necessária aos peixes. Deixá-la ou ser de ela retirados significa irremediavelmente o seu fim.

${ }^{26}$ Talmud da Babilônia, tratado Berakhot, 61b. 
Após uma frase apresentando a personagem da raposa à beira d'água, o desenvolvimento da narrativa é marcado pela progressão do diálogo entre a raposa e os peixes:

$\checkmark$ questão relativa a sua atitude de fuga

$\checkmark$ motivo invocado: medo das redes dos homens

$\checkmark$ proposta da raposa baseada sobre a afirmação da boa experiência vivida no passado entre peixes e raposas

$\checkmark$ recusa dos peixes que apontam a evidência: a terra seca não pode ser senão o seu lugar de morte (fora ou dentro da goela da raposa). Os peixes aproveitam para desmascarar e desprezar essa raposa considerada matreira: 'Não passas de uma estúpida!'

Para os ouvintes, uma interrogação permanece na argumentação da raposa, quando afirma que é possível viver juntos 'como moravam meus pais e os vossos pais': será que a raposa é tão 'estúpida' para afirmar isto? 


\section{CAPÍTULO III}

\section{MASHAL vS NIMSHAL \\ E A EXTRAVAGÂNCIA DA PARÁBOLA}

\subsection{MASHAL vS NIMSHAL - REFERÊNCIA}

No capítulo anterior, iniciamos o estudo das parábolas pela análise da estrutura narrativa, das oposições e das transformações no desenvolvimento da intriga, das tensões e do momento de crise. Seguimos assim as regras do gênero dramático. As duas etapas metodológicas de Fraenkel, a saber, a determinação do modelo de base e a análise da trama, correspondem a estes primeiros passos.

Se parássemos aí, o enfoque seria posto sobre o código em si da parábola. Em uma perspectiva de análise estruturalista, este código se tornaria até essencial, porém em detrimento da mensagem da parábola. Os trabalhos de Ricoeur visam evitar o perigo de uma análise que permaneceria no mero âmbito das estruturas narrativas. Ao comentar este gênero de estudos, ele afirma de maneira lapidar: "Podemos então dizer que explicamos o mito, mas não que o interpretamos" (RICOEUR, 2006, p. 153). Em outros termos, trata-se de passar do sentido da parábola ao seu significado, i.e., o que ela diz sobre a realidade, sobre o mundo; a parábola é, como a linguagem em geral, um meio de discurso aberto e voltado para o mundo.

Notemos que a maioria das parábolas rabínicas são introduzidas pela fórmula consagrada: "Parábola. A que isto é semelhante?" 27 O essencial é o isto a propósito do qual a parábola é contada, e não a parábola em si. A parábola é apenas um 'pavio de ínfimo valor', o essencial é a 'moeda de ouro' ou a 'pérola preciosa' como nos indicaram os Sábios.

\footnotetext{
משל למה הדבר דומה
} 
Esta 'pérola preciosa' encontra-se no nimshal, termo já mencionado no capítulo 1 deste estudo. Os autores de parábolas marcaram freqüentemente a passagem da narrativa parabólica a sua referência pelo termo 'assim':

- 'assim' seguido do versículo bíblico (parábola dos morangos);

- 'assim o Santo-Bendito-Seja-Ele disse' (parábola das vestes reais);

- 'também para ti é assim' (parábola da raposa e dos peixes).

Fraenkel está em perfeita consonância com Ricoeur sobre a questão da referência das narrativas. As parábolas de Hazal, que Fraenkel estuda, são parábolas religiosas. Não é então surpreendente que o foco seja posto na realidade extra-lingüística ou metalingüística, no mundo religioso de Israel. $O$ mashal é antes de tudo destinado a interpretar esta realidade religiosa, 'parabolisada' no nimshal.

Mashal e nimshal não podem ser separados. Esta condição influi sobre a própria composição das narrativas rabínicas. Por isso, Fraenkel insiste sobre uma regra metodológica a ser respeitada:

devido ao fato que o autor de um mashal o elaborou a fim de interpretar de novo o nimshal, é evidente que ele pensou constantemente no nimshal no momento de compor o mashal. Aquele que analisa o mashal deve fazer o mesmo. (FRAENKEL, 1991, p. 331, tradução nossa) ${ }^{28}$

A composição da parábola está a serviço deste liame entre mashal e nimshal. A etapa seguinte da análise do mashal consistirá então em estabelecer as correspondências entre os elementos do mashal e aqueles do nimshal, fazendo um vai-e-vem constante entre os dois. Se, como afirma Fraenkel, o mashal foi elaborado em função do nimshal, pode-se supor que cada detalhe do mashal terá um correspondente no nimshal; nenhuma formulação é por acaso. Este vai-e-vem é portanto necessário. Retomando a

\footnotetext{
"מכיוון שהממשל בנה את המשל כדי לפרש מחדש את הנמשל, מובן מאליו שהוא הרהר בכל רגע בנמשל 28 בשעת עשיית המשל, וגם על הפרשן ללכת בדרך זאל זאת."
} 
formulação de Fraenkel: o mashal e o nimshal mutuamente se interpretam. Elementos do versículo e do comentário que precedem às vezes o mashal serão igualmente objeto de correspondência com a parábola.

\title{
3.2 A EXTRAVAGÂNCIA DO MASHAL - PARA ALÉM DO MODELO DE BASE
}

Ricoeur afirma que um dos traços da metáfora viva é a torsão que ela exerce sobre as palavras, o desvio que ela introduz na linguagem, a fim de criar uma impertinência semântica, que é uma resposta a uma certa incoerência do enunciado. É justamente aí que opera o poder criador da metáfora, que graças a um erro calculado, explora novos campos semânticos.

O mashal de Hazal se mantêm na linha reta desta metáfora impertinente. Com efeito, a maioria das suas parábolas reservam ao ouvinte um efeito de grande surpresa. Freqüentemente, elas o deixam perplexo ante o lado incompreensível da narrativa, ou ainda ante o seu lado extravagante, pelo menos à primeira vista. Pensemos, por exemplo, no servo da parábola que recebe o conteúdo da jarra em plena cara, quando está cumprindo o seu dever. Ricoeur, quanto a ele, fala do

\begin{abstract}
contraste entre o realismo da narrativa e a extravagância, do desfecho e dos principais personagens. A "extravagância" não seria um traço especificamente "religioso" da parábola, semelhante à "intensificação" no provérbio e à liberação de símbolos temporais, além da interpretação literal, nos mitos escatológicos? (RICOEUR, 2006, p. 136, grifo do autor)
\end{abstract}

Esta extravagância tem decerto como objetivo prender a atenção dos ouvintes. Objetivo este que não é em primeiro lugar retórico (Fraenkel se recusa classificar a parábola de Hazal como sendo retórica). Estes elementos incompreensíveis, surpreendentes, e mesmo escandalosos, formam o próprio lugar da criação da parábola. São os indícios que convidam ou forçam o ouvinte a ir além do quadro estabelecido, do modelo de base da parábola. 
Fraenkel fala de um 'perpassar do modelo de base' ${ }^{29}$. Este perpassar representa às vezes uma verdadeira explosão do quadro humano no qual a parábola parecia tão bem se adequar, permitindo-lhe inovar, à maneira da metáfora. Ela será então parábola viva.

\subsection{ESTABELECIMENTO DE CORRESPONDÊNCIAS E EXTRAPOLAÇÃO DO MODELO DE BASE}

Prosseguiremos agora com a análise das 5 parábolas escolhidas seguindo o novo passo metodológico proposto por Fraenkel: a correspondência entre o mashal e o nimshal, e o ultrapassar do modelo de base.

\subsubsection{MASHAL DA JARRA D'ÁGUA}

A compreensão deste mashal é simplesmente impossível sem o nimshal, mesmo que este não esteja explicitamente formulado e deva ser deduzido do contexto da parábola. Esta é inserida ao fim de um capítulo do tratado Suká da Mishná sobre a festa de Sukot e da tenda, habitação provisória e súmaria, na qual o judeu religioso deve habitar durante os sete dias da referida festa. ${ }^{30} \mathrm{~A}$ mishná pergunta a partir de qual intensidade de chuva é permitido deixar a suká e voltar para casa.

A correspondência entre mashal e nimshal se estabelece assim:

\begin{tabular}{|c|c|}
\hline servo & judeu \\
\hline senhor & Deus \\
\hline encher a taça & cumprir o mandamento da Torá \\
\hline
\end{tabular}

\footnotetext{
פריצת דגם היסוד 29

${ }^{30}$ Cf. Ne 8,14.16-18 por exemplo.
} 
O modelo de base deste mashal estabelece que o servo faz o seu dever enquanto que o senhor pode agir como quiser. A análise a partir da relação mashal - nimshal

- confirma que habitar na suká é um dever (religioso) e o senhor / Deus pode aceitar ou recusar este cumprimento (enquanto senhor, ele age como bem entender).

- estabelece que o líquido derramado sobre a cabeça corresponde à chuva durante a festa de Sukot que obriga a deixar a suká.

- mostra que a chuva durante Sukot não vem por acaso, mas ela é a vontade do senhor / de Deus. O senhor do mashal decidiu virar a jarra sobre o seu servo: Deus decide fazer cair a chuva sobre seu servo. A chuva toma aqui uma dimensão religiosa.

Começa-se a entender melhor a extravagância desta parábola, sem portanto esgotar seu sentido. Nada é dito sobre a motivação do rei / Deus, nem no mashal nem no nimshal. Este último ponto depende da inovação e do desvelamento operados pela parábola. (cf. capítulo seguinte)

\subsubsection{MASHAL DAS VESTES REAIS}

Iniciamos a análise desta parábola no capítulo anterior segundo o seu modelo de base rei / servos e segundo a trama da narrativa. Com a colocação em paralelo mashal / nimshal aparecem as correspondências seguintes:

\begin{tabular}{|c|c|}
\hline rei & Deus \\
\hline servos & judeus / humanos \\
\hline
\end{tabular}




\begin{tabular}{|c|c|}
\hline vestes reais & sopro / espírito / alma \\
\hline $\begin{array}{c}\text { dobrar as vestes e devolvê-las } \\
\text { impecáveis }\end{array}$ & cuidar do sopro / espírito \\
\hline $\begin{array}{c}\text { vesti-las, ir com elas ao trabalho e } \\
\text { devolvê-las sujas }\end{array}$ & $\begin{array}{c}\text { negligenciar o sopro / espírito + } \\
\text { transgressões }\end{array}$ \\
\hline o rei pede as vestes & a morte \\
\hline alegria / cólera do rei (paz / prisão) & $\begin{array}{c}\text { julgamento após a morte (paz / } \\
\text { prisão) }\end{array}$ \\
\hline
\end{tabular}

A trama do próprio mashal havia indicado como compreender o verbo 'distribuir'. Tendo o rei pedido as vestes de volta, este distribuir não era de nenhuma forma sinônimo de doar. O nimshal confirma este ponto, pois, na perspectiva rabínica, o sopro-espírito não cessa de pertencer ao criador. Os humanos não são senão os depositários.

Outro ponto do mashal reflete bem a teologia rabínica: a afirmação de um julgamento das ações humanas individuais e a afirmação de uma vida possível após a morte. As citações dos versículos de Isaías e de $1 \mathrm{Sm}$ permitem fazer uma nítida distinção entre corpo e espírito, mas deixam também algo nebuloso. De fato, contrariamente à afirmação farisaica da ressurreição dos corpos, os versículos bíblicos permitem somente uma vaga alusão: 'eles estarão em repouso'. A correspondência entre mashal e nimshal não é então perfeita.

A associação de 'vestes' com 'sopro-espírito' demonstra tanto correspondências como certas incoerências. Na perspectiva rabínica, pode-se citar a título de correspondências:

a) tanto a veste quanto o sopro existem antes do nascimento e continuam após a morte.

b) a veste não pertence ao homem, nem o sopro.

c) pode-se lavá-la, da mesma forma que o homem pode se arrepender. 
A desvantagem é que a veste é exterior, ao passo que o sopro é interior. Isto não impede os autores dos meshalim de utilizar esta imagem que tornou-se um topos da literatura rabínica. A interpretação religiosa desta imagem - no quadro de um mashal religioso - é que Deus vê o sopro-espírito assim como os humanos vêem as vestes exteriores.

Essas incoerências são também o sinal da composição dos trechos da literatura rabínica. Eles não são compostos linearmente, mas são muitas vezes a junção de diversos elementos avulsos.

Um ponto de interrogação permanece na trama da parábola: se o rei quisesse o bem de seus servos, porque não lhes disse claramente que ele retomaria as vestes, que estas seriam somente um empréstimo? Por que ter concebido o que assemelha-se a uma armadilha? A extravagância, a impertinência da parábola continuam intactas. É como se, retomando as palavras de Ricoeur, explicássemos a narrativa, mas sem interpretá-la, e isto, mesmo recorrendo ao nimshal.

A última questão permanece: o que esta parábola rabínica nos vem desvelar?

\subsubsection{MASHAL DA RAPOSA E DOS PEIXES}

Nesta parábola atribuída a Rabi Aqiva, as correspondências entre mashal e nimshal assim aparecem:

\begin{tabular}{|c|c|}
\hline peixes & povo de Israel \\
\hline $\begin{array}{c}\text { peixe que permaneceu na água } \\
\text { e foi apanhado }\end{array}$ & $\begin{array}{c}\text { Rabi Aqiva que permaneceu com a } \\
\text { Torá e foi preso }\end{array}$ \\
\hline $\begin{array}{c}\text { peixe que saiu da água } \\
\text { para subir na terra firme }\end{array}$ & $\begin{array}{c}\text { Papos que deixou a Torá } \\
\text { [mas foi preso] }\end{array}$ \\
\hline raposa estúpida & Papos (?) \\
& [qualificado de 'tolo' por R. Aqiva] \\
\hline
\end{tabular}




\begin{tabular}{|c|c|}
\hline pescadores & reino perverso [Roma], não judeus \\
\hline rio, água & a Torá e seu estudo \\
\hline terra firme & lugar de morte, fora da Torá \\
\hline
\end{tabular}

Esta narrativa mostra que o reino de Roma, os pescadores, procuram constantemente capturar Israel, levá-lo à terra firme, por meio das redes que eles confeccionam. Porém, ela parece dizer igualmente que é 'da natureza' destes homens pescar peixes. Sempre foi assim. Que os peixes não se iludam sobre uma possível trégua entre os dois grupos: a terra firme, reino de Roma, será sempre seu lugar de morte. Este reino de Roma é qualificado de 'ímpio'. Não pode ser diferente, do ponto de vista dos peixes.

A única saída para os peixes é permanecer agrupados e fugir de um lugar para outro (é a versão de certos manuscritos). Notemos que o termo medo aparece na fala de Papos, mas o narrador não o utilizou para justificar a atitude dos peixes. Eles simplesmente afirmam que é 'por causa das redes e das armadilhas que fazem os humanos para prender-nos'. Como se o medo não tivesse lugar aqui, pois os peixes não têm ilusão sobre o fim da história. $A$ melhor saída é então continuar o curso normal da vida, a imersão na águaTorá. É por isso que Rabi Aqiva é encontrado 'sentado interpretando [a Torá], fazendo assembléias públicas, e com um livro da Torá em seu colo'.

Papos faz parte deste grupo de peixes: ele é um judeu como Rabi Aqiva; no entanto, ele decidiu subir para a terra firme, seguindo os conselhos da raposa. No mashal, ele expressa a voz desta última, aconselhando Rabi Aqiva a deixar a Torá: 'Aqiva, não tens medo deste governo?'. Essa correspondência possível é reforçada pelas palavras 'estúpida' que qualifica a raposa e por 'tolo' que qualifica Papos. Porém, ele não parece querer armar uma armadilha para Rabi Aqiva, contrariamente à raposa que procura, como os homens, atrair os peixes para a terra firme, a fim de 'morarmos juntos, eu e vós, como moravam meus pais e os vossos pais'. A decisão de Papos de subir para a terra firme / de deixar a Torá, de nada adiantou: ele foi preso, e se junta a Rabi Aqiva na prisão. 
Podemos interpretar esses diversos elementos da seguinte forma: Papos é decerto um peixe e queria o bem de Rabi Aqiva e da comunidade, mas, aconselhando a deixar a água / Torá, ele não é senão uma raposa má.

\subsubsection{MASHAL DO ARRENDATÁRIO}

A passagem bíblica que o mashal interpreta é a seguinte:

Abel apascentava as ovelhas, Caim cultivava o solo. No fim da estação, Caim trouxe ao Senhor uma oferenda de frutos da terra; também Abel trouxe primícias dos seus animais e a gordura de eles. O Senhor voltou seu olhar para Abel e sua oferta, mas de Caim e da oferenda que trouxera desviou o olhar. (Gn 4, 2b-5a)

Estes versículos suscitam naturalmente a questão de saber por que a oferenda de Caim foi recusada ao passo que aquela de Abel foi aceita. Nenhum motivo aparece no texto bíblico. O mashal remediará esta aparente lacuna.

A importância do modelo de base foi assinalada no capítulo II. Nesta ocasião foi já antecipada a questão das correspondências entre mashal e nimshal nesta narrativa (2.2.2.1). O colocar em cena de uma relação proprietário-arrendatário obriga a compreender a 'oferenda' do versículo como sendo o pagamento para o aluguel da terra, e não uma oferenda sobre uma base voluntária.

As correspondências assim se estabelecem:

\begin{tabular}{|c|c|}
\hline proprietário / rei & Deus \\
\hline arrendatário & Caim \\
\hline & [a palavra 'primícias' aparece a \\
comer as primícias & respeito da oferenda de Abel, mas \\
& não a respeito de Caim] \\
\hline
\end{tabular}




\begin{tabular}{|l|c|}
\hline entregar frutos derradeiros & $\begin{array}{c}\text { frutos avariados } \\
\text { [segundo a derashá] }\end{array}$ \\
\hline
\end{tabular}

As correspondências estabelecidas convidam a completar, por assim dizer, o texto bíblico. É afirmado pelo mashal que o arrendatário-Caim reserva para si mesmo primícias da colheita. Ora, fala-se de primícias somente com relação à oferta de Abel. Os comentadores podem então supor que a não menção do termo 'primícias' acerca da oferenda de Caim significa que ele as reservou mesmo para si.

Mas, como afirmar que estes frutos são derradeiros e de má qualidade? O mashal reflete aqui a palavra psolet (algo avariado) do comentário. Ele se apóia igualmente sobre uma exegese nova do versículo: a expressão 'ao fim de certo tempo' é reinterpretada e compreendida como sendo 'ao fim do tempo [da colheita]', i.e., quando sobram somente os últimos e maus frutos. É sobre esta base que a derashá, posta antes da parábola, pode igualmente afirmar que os frutos estão avariados.

Esta nova exegese do versículo, assim como as correspondências mashal-nimshal, permitem qualificar Caim de 'mau arrendatário', como o faz o mashal. A língua utilizada pelo autor revela também toda a sua ironia: Caim 'oferece' (mekhabed = literalmente 'honra') o rei com frutos derradeiros. O qualificativo aplicado a Caim é então justificado pela sua atitude revelada pelo mashal, atitude que nada, no texto bíblico, permitia supor. A atitude de Deus que recusa a 'oferenda' de Caim torna-se então compreensível.

\subsubsection{MASHAL DO LADRÃO DE MORANGOS}

Este mashal é seguido da palavra 'assim' que introduz um versículo bíblico: 'A voz do sangue do teu irmão clama a mim'. As correspondências 
entre mashal e nimshal devem então ser estabelecidas com os versículos que precedem e seguem o mashal.

Dá-se o seguinte paralelo:

\begin{tabular}{|c|c|}
\hline proprietário do pomar & Deus \\
\hline ladrão & Caim \\
\hline furto dos morangos & assassinato de Abel \\
\hline pergunta 'que tens em tuas mãos?' & pergunta 'Onde está teu irmão Abel?' \\
\hline resposta do ladrão: & resposta de Caim: \\
'nada' & 'Sou o guarda do meu irmão?' \\
\hline tuas mãos estão manchadas & A voz do sangue do teu irmão \\
& clama a mim \\
\hline
\end{tabular}

$\mathrm{Na}$ análise da narrativa, perguntamos se o proprietário do pomar havia visto o furto. A própria narrativa havia respondido a esta questão pela afirmativa ao introduzir a fala do proprietário: 'que tens em tuas mãos?' Este ponto encontra sua plena confirmação no paralelo feito com o nimshal. Se o proprietário do pomar representa Deus, este é onisciente e sabe então que o furto / assassinato foi cometido.

Mas o nimshal traz um novo elemento quanto a atitude do ladrão e de Caim. Se o ladrão nega o furto, é porque pensa que o proprietário não o viu. Da mesma forma, Caim nega saber onde está seu irmão, porque pensa que Deus não teria visto o seu crime. Nisto ele se engana evidentemente, ao esquecer-se (ou ao fingir esquecer-se) que todas as suas ações são vistas por Deus.

Outro elemento é valorizado graças ao nimshal: as 'mãos', elemento central da narrativa. Estas mesmas mãos cometeram o assassinato, eis porque elas estão manchadas, e continuarão provavelmente assim, como sinal indelével (talvez uma alusão indireta a Gn 4,15 "E o Senhor pôs um sinal sobre Caim").

Uma questão continua, contudo, sem resolução: se o proprietário deste pomar é onisciente, por que perguntar 'que tens em tuas mãos?', como se ele 
não soubesse que essas mãos cometeram o furto? Esta pergunta corresponde no nimshal à pergunta de Deus: 'Onde está teu irmão Abel?', como se Deus não soubesse do crime de Caim. Os elementos de possível resposta constituirão o desvelamento de um novo sentido na interpretação bíblica. (Cf 4.2.1) 


\title{
CAPÍTULO IV
}

\section{O MASHAL DESVELA A TORÁ}

\subsection{A METÁFORA E A PARÁBOLA INOVAM}

Os trabalhos de Ricoeur que extraíram a metáfora do império da retórica mostram quanto esta é capaz de re-descrever a realidade, reorganizar uma certa visão das coisas, inovar sobre o plano semântico. A função principal da metáfora é fazer emergir um sentido novo. A metáfora cria sentidos.

Ricoeur se refere a esta função criadora da metáfora por analogia aos modelos no mundo científico:

\begin{abstract}
A metáfora é para a linguagem poética o que o modelo é para a linguagem científica quanto à relação com o real. Ora, na linguagem científica, o modelo é essencialmente um instrumento heurístico que visa, por meio da ficção, destruir uma interpretação inadequada e traçar um caminho para uma interpretação mais adequada. (RICOEUR, 2000, p. 366)
\end{abstract}

Este poder criador da metáfora encontra-se também na narrativa - e conseqüentemente na parábola - por este fenômeno de inovação semântica. De fato, algo novo, inédito, surge igualmente na narrativa, pela intriga fingida, pela nova congruência em sua tessitura. Tanto na metáfora quanto na narrativa desabrocha-se a criatividade humana.

A metáfora e o enunciado metafórico que é a parábola são então destinados a fazer algo novo. No caso das parábolas rabínicas, que são parábolas religiosas, esse novo dirá respeito ao mundo religioso de Israel, suas interpretações da Torá, suas práticas, sua leitura da história de Israel, etc. Lembremos a formulação da parábola do pavio: 
Nossos mestres dizem:

que o mashal não seja considerado fácil aos teus olhos, pois graças a esse mashal, pode-se compreender as palavras da Torá.

Resta-nos ver o que as cinco parábolas estudadas nos ensinam de novo sobre a Torá e o mundo de Israel, e como elas o fazem. As interrogações que permaneceram em suspenso no estudo de cada uma delas, serão justamente o ponto de partida desta última etapa de análise, último passo metodológico proposto por Fraenkel: qual é o novo elemento, a nova verdade religiosa descoberta pelo mashal rabínico? Trataremos primeiramente dos três meshalim que reinterpretam um versículo bíblico.

\subsection{EXEMPLOS DE DESVELAMENTOS NOS MESHALIM}

\subsubsection{MASHAL DO LADRÃO DE MORANGOS}

Deixamos a análise deste mashal com uma pergunta não resolvida: tanto o proprietário do pomar como o Deus da narrativa bíblica fingem não saber o que aconteceu. Esse fingimento lhes permite fazer perguntas aparentemente inúteis, ou cuja resposta só confirmaria o que eles já sabem: 'que tens em tuas mãos?' e 'onde está o teu irmão?'

Estas perguntas têm sobretudo por objetivo pôr de lado uma acusação imediata tanto do proprietário quanto de Deus onisciente: 'eu te vi, tu és culpado'. Assim, elas criam um espaço - e um momento de silêncio e de reflexão possível - tanto para o ladrão de morangos quanto para Caim. Eles deveriam dar-se conta que o proprietário-Deus os viu e que ele lança uma indireta graças a esta pergunta. Um espaço é aberto com efeito para reconhecer sua falta. Esta oportunidade não foi aproveitada pelos dois personagens que negam toda e qualquer participação. Eles mesmos fecham a possibilidade de confessar a sua culpa e a possibilidade de um arrependimento. A conseqüência é inevitável: eles são imediatamente 
encurralados: 'tuas mãos estão manchadas', 'a voz do sangue do teu irmão clama a mim'.

Se tal foi a intenção do autor do mashal, compreende-se por qual motivo ele escolheu colocar em cena o proprietário do pomar e não o guarda. Somente o proprietário pode se permitir perdoar o furto, a supor que haja confissão da culpa. Um simples guarda não poderia atribuir-se este papel. $O$ modelo de base escolhido confirma então a possibilidade de interpretação avançada aqui.

Esta interpretação não segue evidentemente o sentido óbvio do versículo bíblico. Mas notemos que ela foi retida por Rashi no seu comentário acerca da pergunta de Deus: 'Onde está teu irmão Abel?' Rashi escreve de fato: 'Iniciou com ele, com palavras gentis, pois talvez se arrependesse e dissesse: 'eu o matei e pequei perante ti'. ${ }^{31} \mathrm{~A}$ interpretação de Rashi confirma e esclarece a interpretação do nosso mashal. Não se pode afirmar com certeza que Rashi tenha se apoiado nele, mas tanto o seu comentário quanto o mashal, mais antigo, fazem parte do feixe de interpretações convergentes na mesma direção.

\subsubsection{MASHAL DO ARRENDATÁRIO}

A colocação em paralelo do mashal e do nimshal mostrou uma nova exegese do versículo bíblico ('ao fim de certo tempo' compreendido como 'ao fim do tempo [da colheita]). Esta nova interpretação midráshica permitiu todo o desenvolvimento da narrativa que qualifica Caim de mau arrendatário. Ela justificou assim que a oferenda de Caim fosse recusada por Deus, ao passo que aquela de Abel foi aceita.

O mashal afirmou também, pela própria escolha do modelo de base, que a palavra 'oferenda' do versículo bíblico não é, no fundo, uma oferenda voluntária, espontânea e livre, uma oferenda que marcaria o reconhecimento pela utilização de um bem que não pertence à pessoa.

Porém, um desvelamento de teor religioso encontra-se também neste mashal. O narrador nos indica que a relação do modelo de base proprietário-

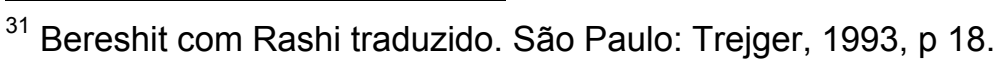


arrendatário, tomada da realidade humana, não funciona aqui perfeitamente. Com efeito, um contrato de arrendamento não se contentaria apenas de afirmar que o arrendatário remeterá uma parte da sua colheita. Ele estipulará a quantidade, a qualidade (certamente não frutos avariados...), a data-limite de entrega, etc. Nada disso é suposto na narrativa que se mostra insólita neste ponto. É justamente o momento no qual ela ensina uma verdade religiosa nova: a simples entrega da oferenda não é suficiente; a atitude da pessoa é o mais importante. Cumprir seu dever somente por cumpri-lo é uma atitude recusada pelo proprietário-Deus. Ele quer, ao contrário, que o arrendatário vá além da relação e dos termos do contrato.

A ultrapassagem do modelo de base opera então uma inversão da proposta inicial de uma mera obrigação para uma verdadeira oferenda pela qual a pessoa expressa livremente sua gratidão.

\subsubsection{MASHAL DA JARRA D'ÁGUA}

As correspondências mashal / nimshal já permitiram amenizar um pouco a extravagância desta parábola: a água derramada sobre o servo corresponde à chuva que Deus faz cair durante a Festa de Sukot. Segundo o texto da Mishná que precede o mashal, quem pratica o mandamento da suká é então autorizado a deixá-la:

Se cair a chuva, a partir de qual momento é permitido deixar [a tenda]? Quando um prato de mingau se estragar [por causa da chuva].

O trabalho de desvelamento se dá justamente no encontro entre esta frase da mishná e o mashal que a segue imediatamente.

Conta-se esta parábola: a que isto pode ser comparado? A um escravo que veio encher a taça do seu senhor, ele [o senhor] virou a jarra na sua cara. 
O primeiro trecho trata da prática dos mandamentos do ponto de vista da halakhá, sendo esta "o conjunto de regras e de leis - derivado da Bíblia, da reflexão religiosa e dos ensinamentos, da jurisprudência e dos costumes - que governa todos os aspectos da vida judaica" (SAFRAI, 1987, p. 121). Este primeiro trecho descreve então uma situação real e objetiva com dois elementos aparentemente antagônicos: de um lado a permanência na suká, de outro a chuva (forte) passando pelos ramos do teto e tornando esta permanência difícil. $O$ texto estabelece um critério que determina até quando é obrigação permanecer na suká, e a partir de quando é permitido deixá-la. Sendo permitido deixar a suká, entende-se que o mandamento foi cumprido.

O mashal afirma com toda a força que Deus se serve da chuva para impedir a permanência da pessoa na suká. E ainda mais, que esta chuva sobre a cara é uma verdadeira humilhação, como aquela do servidor do mashal. Resta à pessoa se perguntar o que provocou a cólera de Deus.

Esta narrativa, como a precedente do 'arrendatário mau' questiona o praticante sobre a sua atitude interior ao cumprir os mandamentos, mas ela o faz de maneira ainda mais incisiva. De fato, o mashal, enquanto texto de agadá $^{32}$, vem questionar a halakhá na sua totalidade: qual é o seu valor se ela permanece somente na dimensão exterior? Notemos que este questionamento encontra-se na própria Mishná, a viga central para a elaboração da halakhá.

\subsubsection{MASHAL DAS VESTES REAIS}

Deixamos esta parábola com uma questão: por que o rei não falou claramente para os seus servos que a distribuição de vestes reais não passava de um empréstimo, e que deveriam cuidar de elas a fim de devolvê-las impecáveis? Tal seria o quadro normal de um rei humano que quer seus servos fazendo a sua vontade.

Porém, o narrador, graças a essa impertinência do mashal que visa uma realidade extra-humana, leva os ouvintes a interpretar esse silêncio do rei / Deus.

\footnotetext{
32 A Agadá abrange os textos de reflexão teológica, as máximas, parábolas, comentários diversos. Em suma, tudo que não é Halakhá.
} 
Nas entrelinhas da parábola, vê-se que os primeiros servos começaram por interrogar-se a respeito do gesto insólito do rei: qual é o seu significado? qual é afinal a intenção do rei? Segundo este mashal, interrogar-se, indagar e refletir é um imperativo. Exatamente o contrário da atitude dos outros servos que não pararam um minuto e continuaram a sua vida normalmente.

O questionamento e a sabedoria para responder às interrogações é o critério por excelência que leva os primeiros servos a penetrar a intenção do rei. Essa sabedoria demonstrada por eles é, por assim dizer, o cofre no qual eles depositaram as vestes, sabendo que o dia de devolvê-las virá.

\subsubsection{MASHAL DA RAPOSA E DOS PEIXES}

As correspondências entre mashal e nimshal desvelaram que

- o 'reino perverso' sempre tentará prender os judeus e tirá-los da água-Torá;

- quem deixa o rio e incentiva os outros a fazer o mesmo torna-se a voz da raposa inimiga que leva os seus correligionários a uma morte certa.

Mas é sobretudo a imagem da Torá como 'água' que permite um desvelamento e uma inovação na interpretação. O par água-peixe é inteligivel imediatamente: fora da água, não há salvação para os peixes. Mas nem os peixes que permaneceram na água escaparam à morte. A narrativa desvela assim que 'a Torá é a condição absoluta para viver apesar de ela não garantir a vida' e que 'ela não livra da morte e não dá a vida, mas é necessária para a vida' ${ }^{33}$ (FRAENKEL, 1991, p. 352, tradução nossa). Quem não descobre esta verdade age como Papos à procura da sua salvação na terra firme. Nela, ele encontra a morte.

No nimshal, a citação do versículo de Dt 20,30 'pois ele é a tua vida e o prolongamento de teus dias' é muito apropriada. Na Bíblia, o versículo é precedido de uma forte exortação a voltar a Deus, praticando a Torá (v.11). Vejamos o fim do capítulo, a partir do versículo 14 :

\footnotetext{
התורה היא תנאי החיים המוחלט אע"פ שאין היא מבטיחה חיים [...] אין התורה מצילה ונותנת חיים אבל היא 33

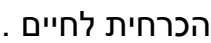


${ }^{14} \mathrm{Sim}$, a palavra está bem perto de ti, está em tua boca e em teu coração, para que a ponhas em prática. ${ }^{15}$ Vê: hoje ponho diante de ti a vida e a felicidade, a morte e a infelicidade, ${ }^{16}$ eu, que hoje te ordeno ames o Senhor, teu Deus, andes nos seus caminhos, guardes os seus mandamentos, suas leis e seus costumes. Então, viverás e te tornarás numeroso, e o Senhor, teu Deus, te abençoará na terra onde entras para dela tomares posse. ${ }^{17}$ Mas se teu coração se desvia, se não o escutas, se te deixas arrastar a prosternar-te diante de outros deuses e servi-los, ${ }^{18}$ eu hoje vos declaro: desaparecereis totalmente, não prolongareis vossos dias no solo em cuja posse vais entrar, quando atravessares o Jordão. ${ }^{19}$ Hoje, tomo como testemunhas contra vós o céu e a terra: foi a vida e a morte que pus diante de ti, a benção e a maldição. Escolherás a vida, para que vivas, tu e tua descendência, ${ }^{20}$ amando o Senhor teu Deus, escutando a sua voz e ligando-te a ele, pois ele é a tua vida e tua longevidade, para habitares no solo que o Senhor, teu Deus, jurou dar a teus pais, a Abraão, Isaac e Jacó. (Dt 30,14-20) ${ }^{34}$ (grifo nosso)

Estes versículos constituem uma espécie de pano de fundo para o nosso mashal. A escolha entre a vida e a morte, tão acentuada nesta passagem, é precisamente o dilema revelado pelo mashal, dilema perante o qual se encontram Rabi Aqiva e Papos. Mas, a escolha de Papos de deixar (temporariamente?) de ocupar-se da Torá, mesmo que motivada pelo medo, pode agora ser assimilada a prosternar-[se] diante de outros deuses (v.17). Notemos, aliás, que alguns manuscritos apresentam uma lição mais explícita que a edição do Talmud de Vilna, falando de um shemad, i.e., devastação e, mais precisamente, uma perseguição religiosa que tem por objetivo levar a apostasia. $^{35}$ Nosso mashal desvelaria então que deixar a Torá, mesmo sem professar ativamente outra fé, já é uma apostasia. Irônica e tragicamente, esta apostasia não subtrai à perseguição: Papos foi preso e acorrentado na prisão.

O versículo 20 merece uma atenção peculiar para o nosso propósito. A expressão 'ligando-se a ele' ${ }^{36}$ reflete no mashal que os peixes / judeus devem permanecer mergulhados na água / na Torá. O versículo prossegue afirmando

\footnotetext{
${ }^{34}$ Versão da Bíblia, Tradução Ecumênica, 1995.

${ }^{35}$ Veja no anexo, texto 6 , nota 60.

ולדבקה-בו
} 
que 'ele [i.e., Deus] é a tua vida' ${ }^{37}$. O nimshal não lê essas palavras segundo o seu sentido literal, mas sim segundo o seu sentido interpretativo. Ele as aplica à Torá "da qual a Escritura diz: 'Porque ele é tua vida'". O pronome masculino, que designava originalmente Deus, se refere aqui ao substantivo feminino Torá. Fazendo este vai-e-vem entre os versículos e o trecho do Talmud, é desvelada em filigrana a concepção dos Sábios que unem Deus à Torá, ao ponto de afirmar que Deus é a Torá.

Nota-se também que a narrativa sobre Aqiva e Papos reflete uma situação de Israel após a destruição do Templo. Esse marcava a presença de Deus, encontrado pelo culto. Segundo os Sábios, a Torá, ou melhor, o TalmudTorá, substitui este culto, e se reveste então de uma suma importância. $O$ mashal é parte deste Talmud-Torá, como o veremos no seguinte capítulo.

\footnotetext{
37 כי הוא חייך. Tradução nossa.
} 


\section{CAPÍTULO V}

\section{O MASHAL: UM TALMUD-TORÁ EM MINIATURA}

\subsection{INTRODUÇÃO}

O título deste capítulo encontra eco na expressão de Ricoeur que qualifica a metáfora de 'poema em miniatura'. Podemos igualmente considerar o mashal como uma miniatura do mundo de Hazal, em geral, e mais especificamente do mundo talmúdico e da sua atividade religiosa e literária que é o Talmud-Torá.

Analisamos nos quatro primeiros capítulos o funcionamento dos meshalim e o seu papel hermenêutico. Porém, eles não podem ser reduzidos a isso. Eles devem ser considerados em uma perspectiva mais abrangente que leve em consideração o mundo literário e religioso-teológico do qual eles brotam. Esses textos expressam de fato o mundo espiritual de Hazal, que se encontra no Talmud e nas outras coletâneas da época. Faz-se necessário agora um vai-e-vem entre o nosso tema 'parábolas rabínicas' e o mundo talmúdico, a fim de melhor perceber porque as parábolas tornaram-se tão apreciadas pelos sábios. Tentaremos seguir assim o conselho do próprio Fraenkel a respeito da pesquisa sobre agadá (aplicável aos meshalim que são narrativas agádicas) quando afirma que precisa ser

imerso no mundo talmúdico (que compreende evidentemente a halakhá), pois se não há Talmud, não há agadá [...] Voltai ao Talmud e tenham receio de interpretar a agadá sem o Talmud, 
pois ele está na alma da agadá! (Fraenkel, 2001, p. 10, tradução nossa) $)^{38}$

\subsection{MASHAL E TALMUD-TORÁ}

\subsubsection{Uma atividade e um questionamento}

Entende-se a relação entre mashal e Talmud-Torá, lembrando o que ocorre com o termo talmud. Antes deste designar uma coletânea de tradições elaboradas a partir da Mishná, o talmud é uma atividade, i.e., o estudar e o ensinar da Torá. Esta atividade produz, por assim dizer, um resultado que é igualmente talmud. Todo o conjunto dessas narrativas e dos debates encontrase compilado nas duas grandes coletâneas que, por sua vez, levam o nome de talmud: o Talmud de Jerusalém e o Talmud da Babilônia.

O mesmo processo ocorre com a palavra midrash. O termo designa primeiramente uma atividade, i.e., a busca do sentido da Escritura, a busca exegética. O termo passa a designar o resultado desta busca e por fim a coletânea inteira que reúne os midrashim. Duas coletâneas aparecem neste estudo: Midrash Bereshit Rabá (mashal do ladrão de morangos e mashal do arrendatário) e Midrash Shir Hashirim Rabá (mashal do pavio).

A palavra agadá apresenta um processo similar, passando da atividade do dizer-ensinar (a respeito de Pessah é dito, por exemplo, "naquele dia transmitirás a teu filho" 39 Ex 13,8), ao resultado colocado sob a forma de narrativa (a Hagadá ${ }^{40}$ de Pessah), até o gênero inteiro chamado agadá.

O termo mashal derivado da raiz M.SH.L que significa enquanto verbo 'ser semelhante a' e, por extensão, 'comparar' é igualmente, e antes de tudo, uma atividade. Trata-se do processo ativo pelo qual os autores colocam em paralelo, colocam em mashal, 'parabolisam'. O mashal é ato de criação artística, ele é esse fazer, essa poíesis, da qual fala Aristóteles. Porém, outro nível de atividade surge com o mashal. De fato, o próprio gênero dramático do

\footnotetext{
שקוע בעולם הלתמודי (הכולל כמובן את ההלכה), ואם אין תלמוד אין אגדה ... שובו אל התלמוד וגורו לכם 38 נגדי

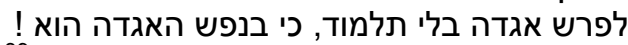

והגדת לבנך היום ההוא

${ }^{40}$ A letra n proveniente da forma hebraica foi mantida na expressão noפ הגדה שלה A forma. אגדה reflete a influência do aramaico. Cf. EVEN-SHOSHAN (1987), verbete אגדה.
} 
mashal obriga os personagens à ação dentro da narrativa. O traço típico das parábolas é o fato dos personagens terem de entender por si mesmos o que acontece na narrativa. E os seus gestos, atos e fala determinam o decorrer da mesma. Eles devem ser conscientes do papel que desempenham: eles criam também o mashal.

O trecho do Talmud da Babilônia, Berakhot $61 \mathrm{~b}$, que comporta o mashal da raposa e dos peixes ilustra perfeitamente o caráter dinâmico da narrativa. Ele começa por um ma'asse hakhamim, uma dessas ações dos Sábios encontradas ao longo do Talmud, que coloca em cena Rabi Aqiva e Papos. Mas, logo, dentro da mesma narrativa, o próprio Rabi Aqiva se torna narrador de um mashal. Esse é mais do que um espelho no qual se refletiria a realidade vivida do ma'asse. A parábola é um verdadeiro prisma pelo qual a realidade deve passar e ser analisada. Saindo do mashal - por assim dizer -, se chega a uma nova realidade (a prisão) vivida por Rabi Aqiva e Papos. Papos demonstra na última frase do trecho ('Feliz és tu, Aqiva, que foste preso por causa das palavras da Torá! Infeliz Papos que foi preso por causa de coisas vãs') que ele passou pelo prisma do mashal e percorreu o caminho proposto por Rabi Aqiva, caminho literário, caminho hermenêutico e caminho interior que o levou a reconhecer a verdade desvelada pelo mashal e por Rabi Aqiva. O Papos do final da narrativa não é o mesmo do início da narrativa; e o próprio personagem marca essa mudança, qualificando-se de 'infeliz Papos'.

O mashal provocou em Papos essa atividade exegética que the fez tomar consciência do seu erro de apreciação inicial. Um passo suplementar deve ser feito: de fato, se o mashal é uma hermenêutica em ação, baseada nas ações das personagens da narrativa, ele requer evidentemente a mesma disposição e dinâmica dos ouvintes e leitores. Esses estão convidados a acompanhar, e talvez se identificar com Papos, com o arrendatário, com o servo que recebe a água na cara etc. Esta dinâmica exigida dos ouvintes nutre a sua reflexão e faz com que o mashal possa atingir o seu alvo: desvelar novas realidades religiosas para a comunidade. Isso é a finalidade primordial e última do mashal. 
O mashal como atividade exegética requer esse mesmo dinamismo dos ouvintes e se inscreve assim perfeitamente na perspectiva do Talmud Torá. Da mesma forma que se entra na página do Talmud, se passeia pelo labirinto da Guemará e dos comentários ao seu redor, para se chegar a novas interrogações, assim se entra na narrativa e no mashal, para se chegar ao nimshal, resultado desvelado pelo caminho percorrido.

Outro ponto faz ponte entre o mashal em particular e o Talmud Torá em geral: a importância da pergunta. Escutemos Safrai, na sua apresentação da Torá oral:

Illuminative of the creative process of Oral Tora is the importance of questions. Asking questions was an essential element in the teaching process [...] Questions of all sorts are found in all the various areas of rabbinic literature, not just in the Talmudim and the midrash collections, but even in the Mishna which is known to have gone through a most rigorous process of editing [...] Questions, as a regular part of the proceedings, could play a notable role. (SAFRAI, 1987, p. 66-7)

Sem pergunta, não há busca, não há Talmud-Torá. Sem pergunta, não há mashal. Sem pergunta, não há desvelamento de novas realidades.

As cinco parábolas analisadas neste estudo giram ao redor de uma ou de várias perguntas. Elas atingem primeiro as próprias personagens das narrativas, mas visam evidentemente os ouvintes, nesta dinâmica hermenêutica à qual eles são instigados:

- o servo no trecho da Mishná, tratado Suká, não pode não perguntar a respeito do motivo que levou o seu senhor a virar a taça na sua cara, da mesma forma que o praticante do mandamento da suká não pode deixar de perguntar-se pela chuva que o obriga a deixar a suká.

- o ladrão de morangos há de enfrentar uma pergunta direta do proprietário.

- o arrendatário deve perguntar-se a respeito da qualidade dos frutos que ele levará ao proprietário, i.e., que qualidade de oferenda a pessoa religiosa oferecerá a Deus. 
- a narrativa sobre Rabi Aqiva e Papos apresenta não menos que seis perguntas (formais ou com expressões entendidas como tais) que pontuam o desenrolar da ação ('Aqiva, não tens medo desse governo [romano]?'; 'Não és tu Papos ben Yehudá do qual dizem ser um grande sábio?'; 'Mashal, a que isto é semelhante?'; 'Por que vós vos juntais [em um lugar] ?'; 'Tu és a raposa da qual dizem ...?'; e enfim: 'Papos, por que te trouxeram aqui?'). Cada pergunta representa uma espécie de crescendo até a última que leva Papos a reconhecer que Rabi Aqiva tinha razão.

- O mashal das vestes reais ilustra de maneira particular a importância da pergunta. Duas atitudes opostas respondem à atitude insólita do rei. Uma delas é precisamente a ausência de pergunta que faz com que os servos continuem sua vida sem nada mudar; a outra é, ao oposto, um questionamento fundamental que vai até adentrar a intenção do rei. Esta capacidade de questionar constitui o coração do mashal e a linha de demarcação entre os sensatos e os insensatos.

Estes questionamentos múltiplos das parábolas remetem ao questionamento do homem que tenta compreender o mundo e sua realidade. Assim são engajadas a responsabilidade e a liberdade humanas, dois temas recorrentes na literatura de Hazal, como o veremos mais adiante.

\subsubsection{Relação entre mashal, Torá escrita e Torá oral}

A fim de continuar a nossa aprimoração do mashal como miniatura do Talmud Torá, convém abordar:

1) a sua relação com a Torá escrita,

2) o seu status dentro do âmbito da Torá oral.

O termo Torá reveste aqui duas dimensões distintas, porém complementares. No primeiro caso, trata-se da Torá escrita, i.e., o Pentateuco (chamado também de Torá no seu sentido mais restrito), os Profetas e os 
Escritos. No segundo caso, trata-se da Torá oral, i.e., os ensinamentos, as tradições homiléticas (agadot), os debates de halakhá que os Sábios elaboraram e transmitiram oralmente, em relação direta ou indireta com a Torá escrita. $\mathrm{O}$ fato desses ensinamentos terem sido colocados posteriormente por escrito não modificou, aos olhos dos Sábios, a sua natureza de Torá oral (Ibid., p.72)

Entre os meshalim analisados neste estudo, três têm uma relação direta com a Torá escrita:

- o mashal do ladrão de morangos está ligado a Gn 4,8-9: "Onde está teu irmão Abel?", etc.

- o mashal do arrendatário comenta Gn 4,3: "Ao fim de certo tempo, Caim trouxe frutos da terra, uma oferenda ao Senhor".

- e o mashal das vestes reais está ligado ao livro de Qohelet: "O sopro volta a Deus que o deu" (Qohelet 12,7).

Nestes três casos podemos constatar que o mashal não vem explicar o peshat dos versículos, i.e., o seu sentido literal e primeiro. Não se trata, por exemplo, de entender a expressão 'ao fim de certo tempo' como uma mera indicação cronológica ou a pergunta 'onde está teu irmão?' como um pedido de informação. Se os meshalim permanecessem no sentido literal dos versículos, o seu alcance seria muito limitado.

Os versículos são decerto o prisma pelo qual autor do mashal aborda a realidade humana, porém, para atingir esse alvo, ele convida a ultrapassar 0 sentido literal e adentrar na complexidade dos versículos e de seu sentido midráshico, a ser ainda desvelado. Ultrapassar a literalidade dos versículos permite ultrapassar a literalidade da realidade humana, a realidade imediata das comunidades que são levadas a refletir graças a esses meshalim. Os servos das vestes reais - e com eles os ouvintes do mashal - podem ultrapassar o mero recebimento das vestes para entender a complexidade da atitude do rei, i.e., a complexidade da relação entre a vida e a morte. O ladrão de morangos deve ultrapassar a literalidade da pergunta 'que tens em tuas mãos?' para perceber, no âmbito religioso, a possibilidade do arrependimento.

Na sua relação com a Torá escrita, o papel do mashal - e do midrash em geral - é então de abrir esta Escritura, que, sem ele, permaneceria restrita, 
fechada em um único sentido. Da mesma forma, as personagens têm que abrir a sua inteligência para entender a intriga do mashal, como o fazem os servos que guardam com cuidado as vestes reais. Eles se tornam então sensatos ou ainda avisados, literalmente: [com os olhos] 'abertos', פקחין. O papel do mashal adquire então suma importância com relação à Torá escrita, que, graças a ele, pode ser desvelada e constantemente atualizada.

Dois meshalim não apresentam uma relação direta com versículos das Escrituras: o mashal da jarra d'água e o mashal da raposa e dos peixes. Constata-se então que o mashal rabínico não está ligado unicamente à Torá escrita; ele pode perfeitamente ser meio de desvelamento dos ensinos da Torá oral (a Mishná e o Talmud da Babilônia nos dois casos acima). O valor e a função do mashal permanecem os mesmos. Com efeito, na concepção rabínica tradicional, a Torá oral tem a mesma origem que a Torá escrita, a saber, a revelação no Sinai. Pode-se até afirmar, nesta mesma perspectiva, que o mashal - como o midrash - é em si Torá oral, e não mero instrumento da mesma. Segundo esta concepção rabínica da Torá, chega-se a uma valorização máxima da natureza do mashal como parte integrante da Torá oral de Israel. Por esta razão, Ihe é permitido questioná-la pelo interior. Vimos por exemplo que a Halakhá que permite deixar a Suká em caso de chuva forte é motivo de um questionamento radical: aquele que pratica o mandamento não pode contentar-se somente com o permitido e proibido da Halakhá. O mashal obriga a ir além da Halakhá, além da estrita observância dos mandamentos ${ }^{41}$. Ele se torna Torá oral criticando a Torá oral.

\subsection{O MASHAL: HARMONIA DE FORMA E DE CONTEÚDO}

Em suas análises de narrativas de agadá, Joná Fraenkel insiste no fato de que "a forma literária é a base mesma, ou melhor a irmã gêmea, do conteúdo ideológico de toda criação artística e um não vai sem o outro" 42 (FRAENKEL, 1981, p. 9, tradução nossa). Um dos seus livros intitula-se de

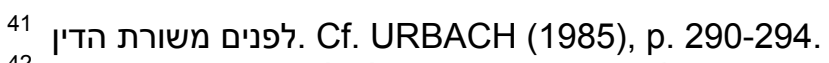

העיצוב הסיפרותי הוא היסוד, או מוטב לומר האח התאום, של התכנים הרעיונים של כל יצירה אמנותית, ואי 42 איום 42 אפשר לזה בלי זה
} 
maneira sugestiva: The Aggadic Narrative, Harmony of Form and Content ${ }^{43}$. Esta harmonia reflete igualmente o que é o mashal no interior do Talmud Torá.

Um ponto capital no processo de criação e de elaboração do Talmud Torá é a liberdade de expressão, tanto na forma quanto no conteúdo, que permite uma constante criação, um renovamento contínuo. Assim como o Talmud - enquanto atividade central de estudo e de ensinamento do mundo religioso de Hazal - aborda os assuntos mais variados, da mesma forma, o mashal toca todos os aspectos da vida religiosa de Israel.

A estrutura do mashal não está fixada em um único modelo. Pode por exemplo não haver versículo, não haver derashá explícita. O nimshal pode igualmente estar ausente; o mashal e o nimshal podem, às vezes, não corresponder perfeitamente (Id., 1991, p. 345). Enfim, a estrutura bastante livre da narrativa que inclui o mashal está em plena sintonia com a liberdade expressa no mundo da agadá de Hazal.

Outro trunfo do mashal é a sua linguagem simples, as suas histórias humanas, sugestivas, pitorescas. Na linha do Talmud-Torá, ele fica ao oposto de um tratado sistemático e abstrato de reflexão religiosa e teológica. O mashal é, antes de tudo, narrativa. E esta narrativa, com frases curtas e diretas, ao alcance de cada um e inseridas na vida concreta das pessoas consegue desvelar de forma profunda a natureza humana e a sua dimensão religiosa.

Notemos também que o mashal não menciona intervenções milagrosas e outros fenômenos sobrenaturais (como a bat qol, a voz celestial). Por isso, ele atinge o ouvinte na concretude da sua situação, convidando a uma reflexão inteiramente humana, mas, ao mesmo tempo, aberta para o suprahumano, uma reflexão humana sobre o religioso. Da mesma forma, o mashal não deixa espaço para o acaso. Assim, o herói deve atribuir-se a responsabilidade do que Ihe acontece (cf. 5.5).

Outra característica da narrativa é o seu gênero de ficção; o mashal não pretende ser outra coisa a não ser uma ficção. Os ouvintes, com certeza, o entenderão como tal. Porém, a ficção remete a um mundo real. Da mesma

\footnotetext{
סיפור האגדה - אחדות של תוכן וצורה 43
} 
forma, os Sábios apontam para o mundo que eles consideram mais real que as aparências deste mundo. Eles apontam, por exemplo, para o verdadeiro valor do mandamento além do cumprimento segundo a Halakhá (mashal da jarra d'água e do arrendatário). No mashal da raposa e dos peixes, Rabi Aqiva, e com ele os Sábios, afirma com força que a morte real é o afastamento da Torá. A outra morte, por mais real que seja, não é a morte. A leitura que Hazal faz da realidade humana encontra então uma expressão perfeita na passagem da fiç̧ão para a realidade que o mashal proporciona.

\subsection{O MASHAL REFLETE OS TEMAS DO TALMUD-TORÁ}

Escrevemos acima (5.3) que o mashal aborda os aspectos mais variados da vida e do pensamento religiosos de Israel. Apontamos também que esta abordagem não é feita à maneira abstrata e sistemática de um tratado teológico. Lembramos aqui a observação de Urbach na introdução do seu livro magistral : Hazal, concepções e crenças ${ }^{44}$, citada por Fraenkel (2001, p. 295):

O ponto comum de todas estas fontes é que não apresentam um tratamento sistemático das opiniões e das crenças dos sábios. E não há quase nenhuma interpretação tratando por completo de um só tema ${ }^{45}$ (URBACH, 1985, p. 3, tradução nossa)

Porém, mesmo considerando a grande liberdade de expressão dos autores e a fragmentação desta expressão em narrativas mais ou menos independentes uma da outra, é possível apontar as linhas mestras do pensamento - ou melhor dos pensamentos - de Hazal. Afirmamos várias vezes que os meshalim são o fruto do beit midrash. É nessas casas de estudos, tanto em Israel quanto na Babilônia, que se desenvolve essa concepção religiosa peculiar do mundo que constitui um tronco comum no mundo dos sábios e seus discípulos, e que eles pretendem transmitir a suas comunidades.

\footnotetext{
חז"ל פרקי אמונות ודעות 44

המשותף לכל המקורות הוא, שבכולם אין לנו דיון שיטתי בפרקי אמונות ודעות, ואין גם כמעט סוגיות רצופות 45 הדנות בנושא אחד.
} 
Temas centrais como a fé em Deus, a sua providência, o estudo da Torá (tanto escrita como oral), a prática dos mandamentos, o valor único do ser humano e seu lugar no mundo, a redenção, são recorrentes na literatura de Hazal (Cf. SAFRAI, 1987, p.101-114). Eles serão evidentemente abordados também pelos meshalim. Nossas cinco narrativas, apesar de elas provirem de fontes diferentes, são elaboradas a partir de um tema comum, a saber, a tensão que existe entre dois pólos: de um lado a liberdade do homem, e do outro o conceito de retribuição, i.e., a recompensa e a punição. Liberdade humana e retribuição divina são duas concepções-chaves no mundo de Hazal.

Os Sábios acreditam que a Providência atua em duas direções: ela governa o mundo e examina os comportamentos humanos. Eles afirmam igualmente que esses comportamentos são decididos em virtude do livrearbítrio do homem. Existe então uma possibilidade de escolha pessoal e, conseqüentemente, a responsabilidade individual do ser humano perante seus atos.

A tensão entre Providência e livre-arbítrio está expressa magistralmente no aforismo talmúdico que se encontra no Talmud da Babilônia, tratado Nida 16b: "Tudo está no poder do Céu, exceto o temor ao Céu". ${ }^{46}$ Segundo esta afirmação, e falas semelhantes nesta perspectiva, a onisciência do divino não impede a escolha humana. Para os Sábios, é então possível escolher entre o bem e o mal, e escolher transgredir. Porém, o individuo deverá assumir as conseqüências das suas escolhas. A concepção bíblica já afirmava o princípio da recompensa e da punição pelos atos humanos, concepção retomada e assumida pelos Sábios do Talmud, porém com um enfoque diferente:

[Os Sábios] tinham a tendência a adiar a retribuição dos atos no mundo de além da morte, ou ainda chegavam à conclusão de que o mandamento é a recompensa do mandamento, e a transgressão a própria punição. (URBACH, 1985, p. 388, tradução nossa). ${ }^{47}$

\footnotetext{
הכל בידי שמים חוץ מיראת שמים 46 של של 46

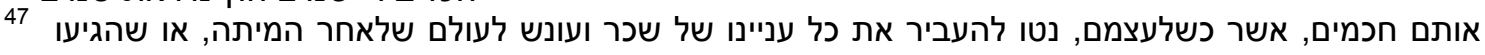
לכלל קביעה, שעצם המצווה היא שכרה, ועצם העברה היא עונשה.
} 
Nas parábolas, o livre-arbítrio é condição sine qua non para que os personagens sejam plenamente atuantes na trama. Esta se desenvolve em função das decisões dos herois, pois eles influenciam sobre o curso da realidade. Mas, as narrativas mostram também que os homens descobrem posteriormente se escolheram bem ou mal, segundo critérios que não lhes pertencem, pois são determinados pelo Céu. Voltamos assim à tensão inicial entre 'tudo está no poder do Céu' e 'exceto o temor ao Céu'.

No mashal sobre Rabi Aqiva e Papos, a prisão deste último pode ser considerada a sua punição imediata, conseqüência da sua decisão de deixar a Torá, ao passo que a prisão decorre, para Aqiva, da sua fidelidade à Torá. 0 servo da jarra d'água é punido imediatamente - e humilhado - por uma atitude ou uma transgressão da qual ele nem tem consciência. O mashal e o nimshal 'das vestes reais' são a ilustração perfeita da tensão entre livre-arbítrio e retribuição. A escolha de uns leva à 'paz', enquanto os outros são 'jogados na prisão'. E nos dois casos, Hazal se apoia em versículos de Isaías e de $1 \mathrm{Sm}$. Notemos que não se trata aqui de uma retribuição imediata, neste mundo, segundo a concepção bíblica (todos os servos continuam a sua vida de servos, sem recompensa peculiar para os sensatos), mas de uma retribuição após a morte, segundo a concepção mais difundida no mundo talmúdico.

O vai-e-vem que fizemos entre o mashal como narrativa e o TalmudTorá revela uma profunda consonância entre os dois. Esta consonância se dá ao nível da natureza da parábola rabínica que é tanto atividade exegética quanto questionamento; dá-se também ao nível da relação que o mashal nutre com a Torá escrita, e do seu próprio status de Torá oral. A forma literária e os temas abordados pelo mashal são igualmente típicos da literatura talmúdica. Parafraseando Fraenkel, citado no início deste capítulo, podemos afirmar que é impossível interpretar o mashal sem o Talmud, pois ele está na alma do mashal. O mashal, por sua vez, pode ser considerado um Talmud-Torá em miniatura. 


\section{CONCLUSÃO}

O objetivo desta dissertação foi expor, à luz dos trabalhos de Ricoeur e de Fraenkel, o mashal rabínico como narrativa metafórica, colocar em evidência seu funcionamento, sublinhar sua função hermenêutica a serviço de um desvelamento da Torá.

No primeiro capítulo, foram expostas as bases teóricas necessárias para a nossa análise. As pesquisas de Ricoeur permitiram reabilitar a metáfora e redescobrir seu imenso potencial. Longe de ser um simples tropo, a metáfora é, antes de tudo, um trabalho sobre a linguagem que cria, por impertinência semântica, algo novo, algo inédito na predicação. É também o que fará a parábola, a parábola-metáfora, que funcionará segundo o mesmo princípio, porém utilizando os meios próprios da narrativa.

Fraenkel é certamente influenciado por Ricoeur. Ele aplica aos meshalim de Hazal as teorias do filósofo francês, desenvolvendo uma terminologia e uma metodologia próprias, e adaptadas à especificidade do mashal rabínico. As conclusões teóricas de um são ilustradas, aplicadas, verificadas e confirmadas pelos exemplos do outro.

Os capítulos dois, três e quatro detalharam este método de Fraenkel. Eles mostraram que o mashal obedece a um modelo de base e que deve ser analisado segundo as regras das narrativas do gênero dramático, onde a tensão reinante na intriga exige um desfecho. Mas o mashal, na ótica de Hazal, não é um fim em si: ele visa o nimshal, que está relacionado na grande maioria das vezes à comunidade de fé de Israel. Convêm então estabelecer correspondências entre mashal e nimshal, entre uma realidade puramente humana e uma realidade vista pelo prisma do religioso. O mashal sofre neste momento uma espécie de explosão: a irrupção do nimshal introduz uma extravagância que derruba o quadro demasiado estreito e racional da narrativa. Aí se revela o poder hermenêutico do mashal que cria, à maneira da metáfora, algo inédito. Graças à sua aparente incoerência, ele surpreende, questiona, mas, sobretudo, desvela um novo olhar, uma nova interpretação, um novo posicionamento. A força do mashal é tal que ele pode chegar a questionar até 
a viga-mestra do mundo de Hazal que é a Halakhá, por sua enérgica injunção a ir além da estrita observância.

O quinto capítulo deste estudo mostrou a perfeita inserção do mashal no Talmud-Torá de Hazal. Ele provoca e exige, tanto da parte dos seus personagens quanto dos seus ouvintes, uma postura dinâmica, um questionamento constantemente renovado. Em outros termos, o mashal vem antes de tudo incomodá-los, e colocá-los em movimento. Nisto encontra-se a sua plena consonância com o estudo-ensinamento que é o Talmud-Torá.

Ao fim deste estudo, podemos constatar que o mashal ocupa uma posição central e serve de ponte entre diversos domínios.

Ele é um excelente instrumento pedagógico, pois sabe aliar uma expressão simples, constituída por imagens populares, acessíveis a todos, a uma sutileza e profundidade de reflexão inigualáveis. Assim, o mundo do Beit Midrash, a casa de estudo, que sempre corre o risco de se fechar em si mesmo e formar uma elite religiosa e intelectual, abre-se para um auditório popular. $\mathrm{O}$ mashal faz sair o Beit Midrash da sala de estudo.

Constatamos que o mashal é tipicamente de cunho agádico e, por isso, pode questionar a Halakhá. As narrativas nas quais isso acontece se encontram então entre a Halakhá e a Agadá, entre o mundo do agir do mandamento, regido pelo permitido e proibido, e o mundo da Agadá, que visa um ideal mais densamente humano e espiritual.

Os meshalim se constituem graças a uma longa sedimentação da tradição interpretativa de Israel, elaborada especialmente pelos Sábios e seus discípulos que estruturam as crenças e opiniões, segundo a expressão de Urbach. Isto nada impede o caráter subversivo do mashal que se caracteriza por uma grande liberdade tanto em sua forma quanto no seu conteúdo. Notemos que o mashal propõe uma interpretação, mas jamais reivindica ser a interpretação. Ele nunca esgota, por exemplo, o sentido de um versículo. Ao contrário, ele suscita novos sentidos, cumprindo assim perfeitamente o seu papel de Torá Oral que renova a Torá Escrita. 
Terminemos com um último paradoxo que os próprios Sábios submetem à reflexão dos ouvintes: o mashal quase nada vale, não mais que um pavio de ínfimo valor. Porém, o mashal não tem preço, pois sem ele, as palavras da Torá, mergulhadas na obscuridade, não poderão ser encontradas:

Mashal de um rei que havia perdido uma moeda de ouro ou uma pérola preciosa, dentro de sua casa;

Não é graças a um pavio de ínfimo valor que ele a encontra?

Assim, que o mashal não seja considerado fácil aos teus olhos, Pois é graças ao mashal que se compreende as palavras da Torá. 


\section{BIBLIOGRAFIA}

Obras e artigos de Fraenkel:

FRAENKEL, Jonah. Bible Verses Quoted in Tales of the Sages. In: Scripta Hierosolymitana, v. 22, Jerusalem: Magnes, 1971. p. 80-99.

. Darkhei haAgadá ve haMidrash (heb) (As vias da agadá e do midrash). Givatayim: Yad LaTalmud (Massada), 1991.

. Iyunim beOlamo haruhani shel sipur haAgadá (heb) (Estudos sobre o mundo espiritual da narrativa de Agadá). Tel Aviv: HaKibbutz Hameuchad, 1981.

. Midrash veAggadá (heb) (Midrash e agadá). Tel Aviv: The Open University of Israel. 1996. Vol 2.

Paronomasia in Aggadic Narratives. In: Scripta Hierosolymitana, v. 27, Jerusalem: Magnes, 1971. p. 27-51.

Sipur haAgadá, Ahdut shel Tokhen veTsura (heb) (A narrativa de agadá, harmonia de forma e conteúdo). Tel Aviv: HaKibbutz Hameuchad, 2001.

Obras e artigos de Ricoeur:

RICOEUR, Paul. Biblical Hermeneutics. In: Semeia Studies n. 4. Atlanta (Ga.): Society of Biblical Literature, 1975. p. 27-148. Paul Ricoeur e a hermenêutica bíblica. In: Paul Ricoeur, a hermenêutica bíblica. Tradução de Paulo Meneses. São Paulo: Loyola, 2006. p. 133-223.

2004.

Ensaios sobre a interpretação bíblica. São Paulo: Novo Século, 
. La métaphore et le problème central de l'herméneutique. In : Revue philosophique de Louvain. Louvain: Faculté des sciences philosophiques: 1970. p. 93-112.

La métaphore vive. Paris: Seuil, 1975. A metáfora viva. Tradução de Dion Davi Macedo. São Paulo: Loyola, 2000.

. Le conflit des interprétations essais d'herméneutique. Paris : Seuil, 1969. O conflito das interpretações: ensaios de hermeneutica . Rio de Janeiro: Imago, 1978

Réflexion faite: autobiographie intellectuelle . Paris : Esprit, 1995.

.Temps et récit. Tome 1. Paris: Seuil, 1983. Tempo e narrativa. Tomo 1. Tradução de Constança Marcondes César. Campinas, SP: Papirus Editora, 1994.

.Temps et récit. Tome 2. Paris: Seuil, 1984. Tempo e narrativa. Tomo 2. Tradução de Marina Appenzeller. Campinas, SP: Papirus Editora, 1995.

.Temps et récit. Tome 3. Paris: Seuil, 1985. Tempo e narrativa. Tomo 3. Tradução de Roberto Leal Ferreira. Campinas, SP: Papirus Editora, 1997.

.Teoria da interpretação. O discurso e o excesso de significação. Lisboa: Ed. 70, 1987.

\section{Fontes primárias:}

AGGADOTH du Talmud de Babylone, La source de Jacob - 'Ein Yaakov. Lagrasse: Verdier, 1982.

BíBLIA Hebraica Stuttgartensia. Stuttgart: Deutsche Bibelgesellschaft, 1967.

BíBLIA, com comentários de Rashi. São Paulo: I.U. Trejger, 1993. Vol.1 (Gênesis). 
BÍBLIA, Tradução ecumênica. São Paulo: Loyola; Paulinas, 1995.

LE TALMUD, L'édition Steinsaltz. STEINSALTZ (org.) Paris: Ramsay, 19942009.

MEKHILTA de-Rabbi Ishmael, com variantes e notas de Shaul Horowitz, 2.ed. Jerusalem: Shalem, 1997.

MEKHILTA de-Rabbi Shim'on ben Yokhai, com introdução, variantes e notas de Ya'akov Nahum Halevy EPSTEIN e Ezra Tsion MELAMED. Jerusalem: Yeshivat Sha'arei Rahamim e Beit Hillel, 1978.

MEKILTA de-Rabbi Ishmael (traduzido por Jacob Z. LAUTERBACH). Philadelphia: The Jewish Publication Society of America, 1961. 3 v.

MIDRASH Rabbá hamevo'ar. [Midrash Rabbá comentado]. Jerusalem: Makhon hamidrash hamevo'ar, 1986.

MIDRASH Rabbá. Com um novo comentário científico de Moshe Arye MIRKIN. Tel-Aviv: Ed.Yavne, 1956.

SHIR ha-Shirim Rabba (Midrash sobre o Cântico dos Cânticos). Jerusalém: Makhon há-Midrash há-mevoar, 1994.

SHISHA Sidrei Mishna (comentados por Hanokh ALBECK). Jerusalem: Dvir, 1988.

SIFREI al Sefer ba-Midbar ve-Sifrei Zuta (Sifrei sobre Números e Sifrei Zuta sobre Números), com variantes e notas de Hayim Shaul HOROWITZ. 2.ed. Jerusalem, Shalem, 1992.

SIFREI al Sefer Devarim (Sifrei sobre o Deuteronômio), com variantes e notas de Eliezer Arie Finkelstein. 3. ed. New York, Beit ha-Midrash le-Rabanim beAmerika, 1993.

TALMUD Bavli. Adin Steinsaltz (ed.). Jerusalém: HaMakhon halsraeli lePirsumim talmudiim, 1966-2009. 
TALMUD da Babilônia. Ed. de Vilna, 1835.

TALMUD de Jerusalém. Krotoshim, 1866

THE MISHNAH, Translated from the Hebrew with Introduction and Brief Explanatory Notes by Herbert DANBY. 8.ed.Oxford: Oxford University Press, 1964.

TORÁ: a lei de Moisés. São Paulo: Sêfer, 2001.

TOSSEFTA, segundo os manuscritos de Erfurt e Viena, com paralelos e variantes de Moshe Shmuel ZUCKERMANDEL, 3.ed. Jerusalém: Wahrman, 1963.

Dicionários, comentários, estudos:

AUERBACH, Erich. Mímesis, A representação da realidade na literatura ocidental. São Paulo: Perspectiva, 2007.

BACHER, Wilhelm. Die Agada der babylonischen Amoräer. Frankfurt-amMain: Trübner, 1913; reimp. 1965.

. Die Agada der Tannaiten. Strasbourg: Trübner, $1903^{2}$, v.2 1890 ; reimp. 1965-1966. v.1.

BENVENISTE, Émile. Problème de linguistique générale. Tome 1. Paris: Gallimard, 1996.

BIALIK, Hayim Nahman; RAVNITZKY Yehoshua Hana. Sefer ha-Aggadah. Jerusalem: Dvir, 1987.

BROWN, Francis; DRIVER, Samuel Rolles; BRIGS, Charles. A Hebrew and English Lexicon of the Old Testament. Oxford: Clerndon Press, 1972. 
BRUNS H. Gerald, Midraxe e alegoria: os inícios da interpretação escritural. In: ALTER Robert, KERMODE Frank (org.). Guia literário da Bíblia. São Paulo: Unesp, 1997. p. 667-689.

DSCHULNIGG, Peter. Rabbinische Gleichnisse und das Neue Testament. Die Gleichnisse der PesK im Vergleich mit den Gleichnissen Jesu und dem Neuen Testament.. Bern: Peter Lang, 1988.

ECO, U. "Metafora". In: Enciclopedia Einaudi. Lisboa: Imprensa nacional Casa da Moeda, 1994. V. 31.

EVEN-SHOSHAN, Abraham. Hamilon hehadash. Jerusalem: Kyriat Sefer, 1987. 4 v.

FLUSSER, David. Die rabbinischen Gleichnisse und der Gleichnisserzähler Jesus. 1. Das Wesen der Gleichnisse. Bern, Frankfurt/Main - Las Vegas : P. Lang, 1981.

GUINSBURG, J. Guia Histórico da Literatura Hebraica, Do Período PósBíblico à Criação do Estado de Israel. São Paulo: Perspectiva, 1977.

JASTROW, Marcus. A Dictionary of the Targumim, the Talmud Babli and Yerushalmi, ans the Midrashic Literature. Jerusalem: Khorev, [1903].

KJÄRGAARD, Mogens Stiller. Metaphor and Parable. A Systematic Analysis of the Specific Structure and Cognitive Function of the Synoptic Similes and Parables qua Metafors, Acta Theologica Danica, n. 20. Leiden: Mogens S., 1986.

KOEHLER, Ludwig; BAUMGARTNER, Walter. Hebräisches und aramäisches Lexikon zum Alten Testament. Leiden: E.J. Brill, 1974.

LAMBDIN Thomas O. Lambdin. Gramática do Hebraico Bíblico. São Paulo: Paulus, 2003.

LIEBERMAN, Saul. Hellenism in Jewish Palestine. Studies in Literary Transmission, Beliefs and Manners of Palestine in the I Century B.C.E-IV Century C.E. New York: Jewish Theological Seminary of America, 1950. 
PÉREZ FERNANDES, Miguel. La lengua de los Sabios: I Morfosintaxis. Estella (Navarra): Verbo Divino, 1992.

PIRES, Orlando. Manual de teoria e técnica literária. Coleção Linguagem 15.

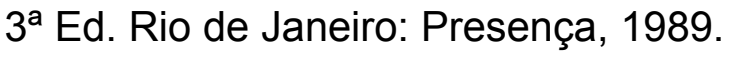

RABIN Hayim. Safot Shemiyot. Jerusalem: Mossad Bialik, 1991.

SAFRAI, Shmuel (Ed.). The Literature of the Sages. Parte I. Philadelphia: Fortress Press, 1987.

Tales of the Sages in the Palestinian Tradition and the Babylonian Talmud. In: Scripta Hierosolymitana, 22. Jerusalem: Magnes: 1971. p. 209232.

SEGAL, Moses Hirsh. A Grammar of Mishnaic Hebrew. Oxford: Clarendon Press, 1970.

STEINSALTZ, Adin. Le Talmud: Guide et lexique. Poitiers: Ramsay, 1995.

STERN, David. Midrash and Theory, Ancient Jewish Exegis and Contemporary Literary Studies. Evanston: Northwestern University Press, 1996.

- Parables in Midrash. Narrative and Exegesis in Rabbinic Literature. Cambridge, Massachussets: Harvard University Press, 1991.

STRACK Hermann Leberecht; STEMBERGER Günter. Introducción a la literatura talmudica y midrasica. [título original: Einleitung in Talmud und Midrash]. Estella: Verbo Divino, 1996.

THOMA, Clemens. Prolegomena zu einer Übersetzung und Kommentierung der rabbinischen Gleichnisse. In: Theologische Zeitschrift, n. 38, Basel: Friedrich Reinhardt Verlag, 1982. p. 514-531.

; LAUER, Simon ; ERNST, Hanspeter. Die Gleichnisse der Rabbinen. Berne : Lang, 1986. 
; WYSCHOGROD Michael (ed). Parable and Story in Judaism and Christianity. New York: Paulist Press, 1989.

URBACH, Ephraïm. Hazal, pirkey Emunot veDeot (Hazal, concepções e crenças). Jerusalém : Magnes, 1985. Tradução francesa : Les sages d'Israël, conceptions et croyances des maîtres du Talmud. Paris : Cerf ; Verdier, 1996.

VIA Dan Otto. The Parables. Their literary and existential dimension. Philadelphia: Fortress Press, 1967.

YOUNG, Bradford Humes. The parables: Jewish tradition and Christian interpretation. Peabody: Hendrickson, 1998.

ZIEGLER, Ignaz Die Königsgleichnisse des Midrash beleuchtet durch die Kaiserzeit (As parábolas de rei à luz da época imperial). Breslau : Schlesische Verlagsanstalt, 1903.

\section{Site na internet:}

Online treasury of Talmudic manuscripts. Developed by the National Library of Israel. Disponível em: <http://jnul.huji.ac.il/dl/talmud/>. Acesso em 30 de dezembro de 2009. 


\begin{abstract}
ANEXO
Textos originais dos meshalim e suas traduções.

Alguns elementos de crítica textual foram acrescentados em notas de rodapé. Eles pretendem justificar a tradução proposta e apontar divergências de lições entre manuscritos.
\end{abstract}

1. MASHAL DO LADRÃO DE MORANGOS (Midrash Bereshit Rabbá, parashá 22, 9)

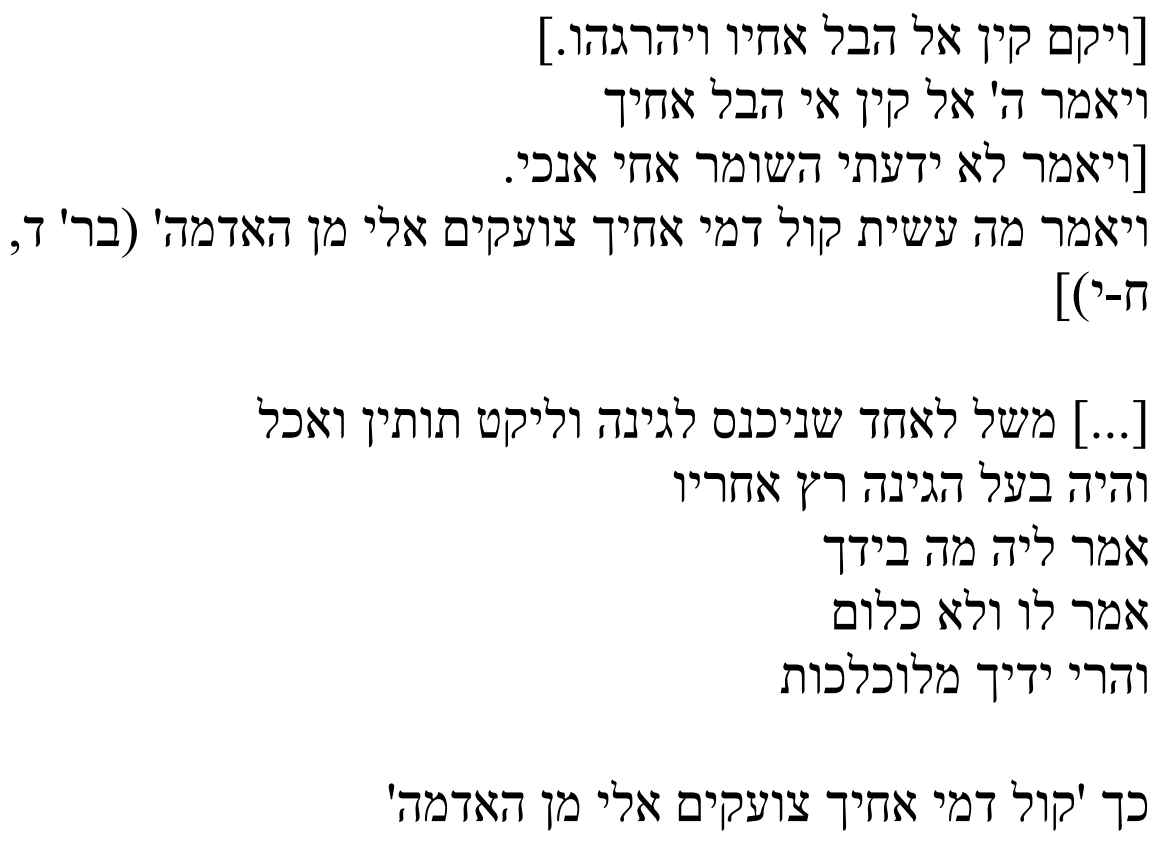

[Caim levantou-se contra seu irmão Abel e o matou].

O Senhor disse a Caim: "Onde está teu irmão Abel?"

["Não sei", disse ele. "Sou o guarda do meu irmão?"

E disse [Deus] "Que fizeste? A voz do sangue do teu irmão clama a mim a partir da terra" (Gn 4,8b-9).]

Mashal de alguém que entrou em um pomar, colheu morangos e os comeu.

O proprietário do pomar correu atrás dele e lhe disse: "Que tens em tuas mãos?"

Ele lhe respondeu : "Nada »

«E no entanto, tuas mãos estão manchadas". 
Assim: "A voz do sangue do teu irmão clama a mim a partir da terra".

2. MASHAL DO PAVIO, (Shir haShirim Rabá, 1,1)

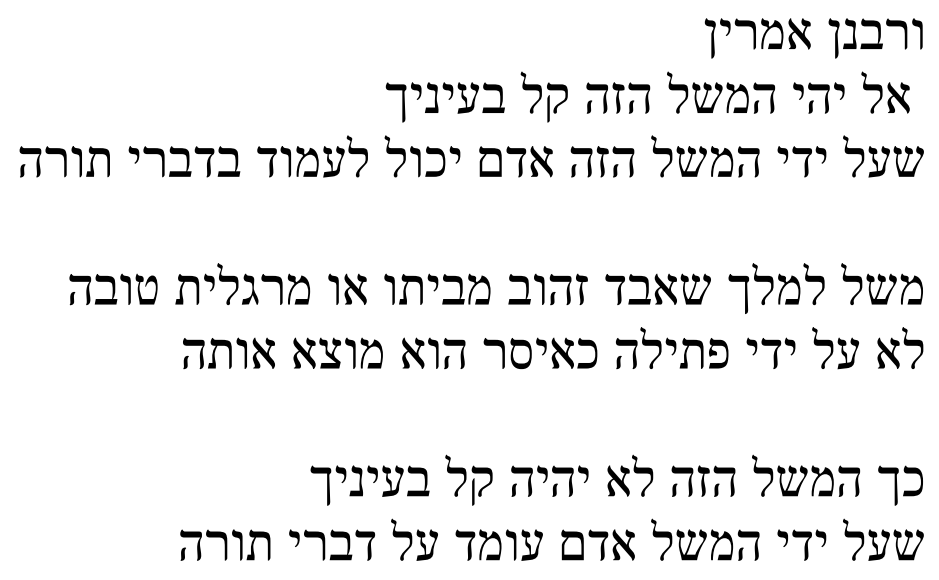

Nossos mestres dizem:

que o mashal não seja considerado fácil aos teus olhos, pois graças a esse mashal, pode-se compreender as palavras da Torá.

Mashal de um rei que havia perdido uma moeda de ouro ou uma pérola preciosa, dentro de sua casa;

Não é graças a um pavio de ínfimo valor que ele a encontra?

Assim, que o mashal não seja considerado fácil aos teus olhos, Pois é graças ao mashal que se compreende as palavras da Torá.

3. MASHAL DAS VESTES REAIS (Talmud da Babilônia, Shabat 152b) ${ }^{48}$

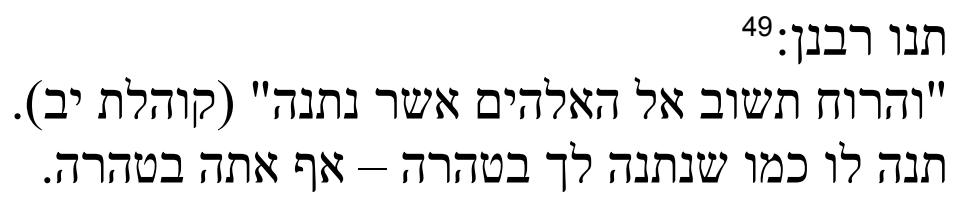

\footnotetext{
${ }^{48}$ Segundo a edição de Vilna do Talmud da Babilônia, 1835, folha 152b.

49 A expressão תנו רבנן: 'nossos mestres ensinaram' introduz uma baraita (literalmente : 'exterior', sendo o ensino de um Tana que não foi incluído na Mishná de Rabi Yehudá haNassi.
} 


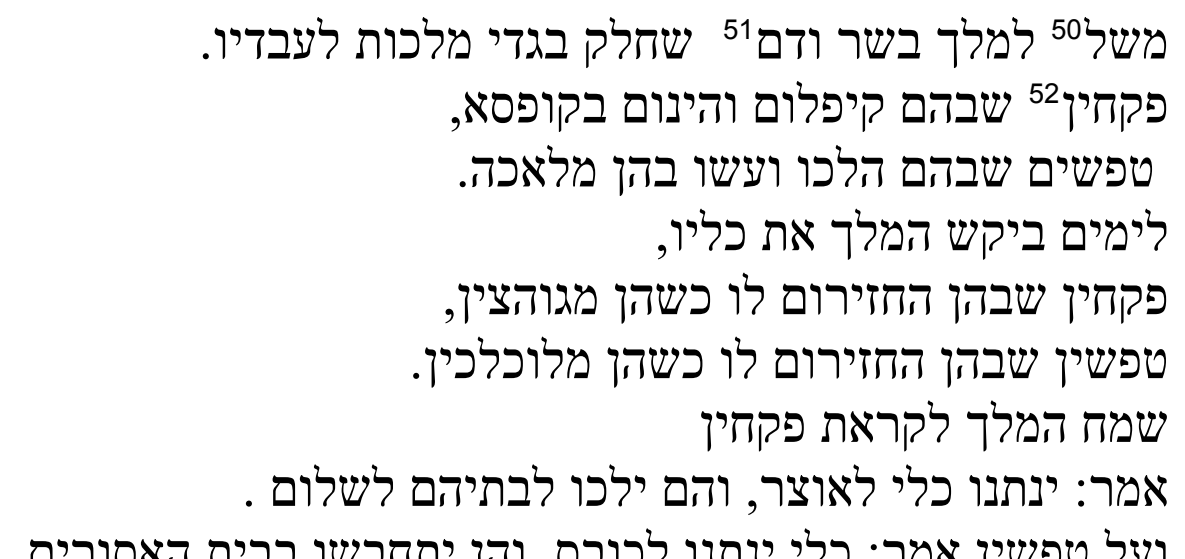

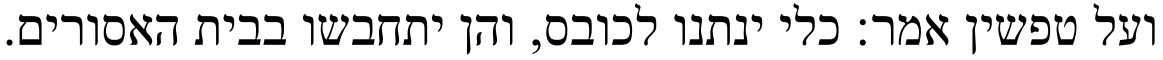

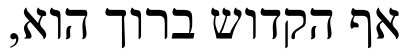

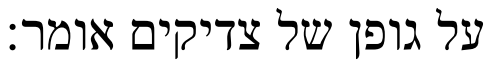 \\ "ויבוא שלום ינוחו על משכלים משרותם" (ישעיהו נז,ב) \\ ועל נשמתן הוא אומר:

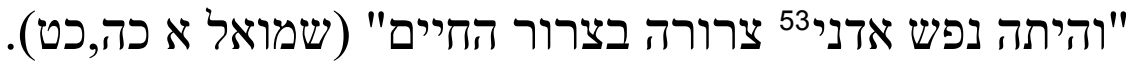

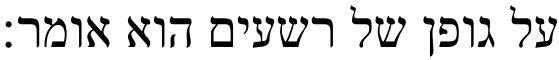

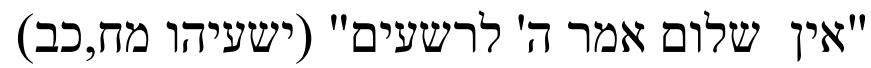

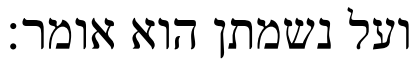 \\ "ואת נפש אויביך יקלענה בתומר: כף הקלע"( שמואל א כה,כט) .
}

\begin{abstract}
Os nossos mestres ensinaram: "O sopro volta a Deus que o deu" (Qohelet 12,7).

Devolve-o a ele como ele o deu a ti: ele o deu a ti puro, devolve-o a ele puro.
\end{abstract}

\footnotetext{
50 O manuscrito Vaticano Ebr.108 da Biblioteca Apostólica do Vaticano acrescenta após a palavra משל a expressão ' 'למה הדבר דומה' : 'a que isto é semelhante?'. Pode ser notado que a continuação do mashal pela palavra 'למלר' encaixa-se perfeitamente, do ponto de vista sintático, tanto após o termo 'mashal': 'parábola de um rei', quanto após 'a que isto é semelhante?' 'a um rei humano'. http://jnul.huji.ac.il/dl/talmud/. Acesso em 30 de dezembro de 2009.

${ }^{51}$ Literalmente: 'rei de carne e sangue', um rei humano.

${ }^{52}$ A raiz significa literalmente 'abrir os olhos' (ou o ouvido). Foi traduzido por 'ser sensato'. A tradução 'ser avisado' conservaria a relação etimológica com o sentido da visão, porém trairia o texto, pois os servos não receberam nenhum aviso ['a visto'], nenhuma informação a respeito das roupas reais. Uma tal tradução impediria uma interpretação do mashal-metáfora, como veremos na análise do mesmo.

${ }^{53}$ A lição do manuscrito Vat. Ebr. 108 é 'נפשם' e não 'נפש אדני' atestado no texto massorético. Vat. Ebr. 108 se permite assim uma adequação do versículo à narrativa, como se o próprio texto bíblico falasse diretamente destes servos sensatos: 'a sua alma'.
} 
Parábola de um rei humano que distribui vestes reais aos seus servos. Aqueles dentre eles que eram sensatos as dobraram e as colocaram em um cofre.

Aqueles dentre eles que eram insensatos as vestiram para ir ao trabalho.

Algum tempo depois, o rei pediu as suas vestes.

Os sensatos as devolveram a ele impecáveis.

Os insensatos as devolveram a ele completamente sujas.

$O$ rei se alegrou com os sensatos e se encolerizou vendo os insensatos. A respeito dos sensatos, ele disse: que minhas vestes sejam colocadas no tesouro e que estes possam ir para suas casas em paz.

A respeito dos insensatos ele disse: que minhas vestes sejam entregues aos lavadeiros e que esses sejam jogados na prisão.

Assim o Santo-Bendito-Seja-Ele disse a respeito do corpo dos justos:

"Mas virá a paz, e estarão em repouso, em seus leitos" (Is 57,2) e a respeito de sua alma, a Escritura diz:

"Mas a vida de meu senhor permanecerá guardada no bornal dos vivos junto do Senhor, teu Deus" (1Sm 25,29).

Mas a respeito do corpo dos maus, a Escritura diz:

"Mas para os maus não há paz, diz o Senhor" (Is 48,22),

e a respeito de sua alma:

"A vida de teus inimigos, o Senhor a arremessará para longe, da cavidade de sua funda" (1Sm 25,29).

4. MASHAL DO ARRENDATÁRIO (Midrash Bereshit Rabbá, parashá 22, 5)

$$
\text { " ויהי מקץ ימים ויבא קין מפרי האדמה מנחה לה' " (בר'ד ג) }
$$

משל לאריס רע שהיה אוכל את הבכורות

\footnotetext{
${ }^{54}$ Adotamos a tradução 'frutos avariados'. O outro termo sinônimo para 'avariado' seria פגום,

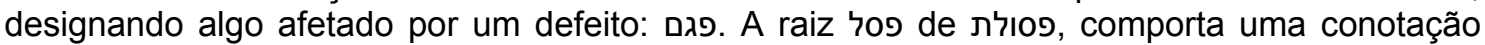
mais forte que o simples defeito, pois ela indica também o que é desqualificado do ponto de vista da halakhá, oposto então ao que é כשר. Trata-se de frutos avariados e 'indignos'. Cf. verbete לספולפ, in: JASTROW , 1984. p. 1192-1193.
} 
ומכבד למלך את הסיפות555

"Ao fim de certo tempo, Caim trouxe frutos da terra, uma oferenda ao Senhor" (Gn 4,3).

Frutos avariados.

Parábola de um arrendatário mau que comia as primícias e entregava ao rei os derradeiros.

5. MASHAL DA JARRA D'ÁGUA (Mishná Sukot 2,9)

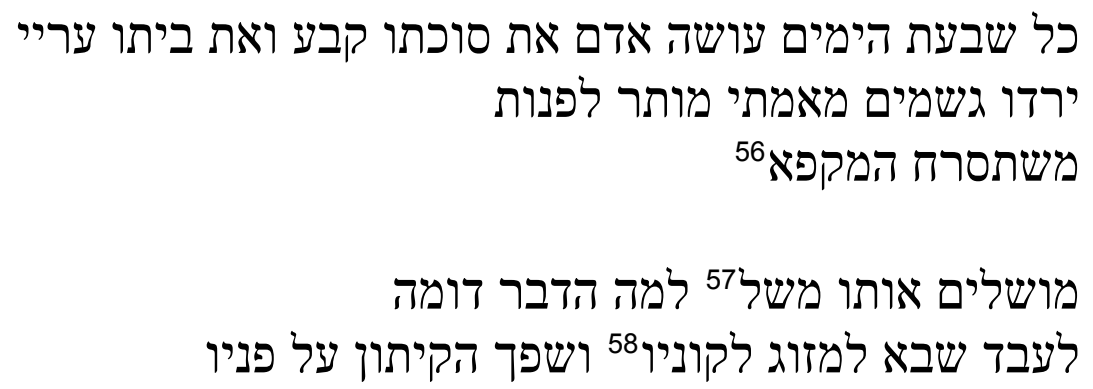

Durante os sete dias [da Festa das Tendas], o homem deve fazer de sua Tenda sua habitação principal e de sua casa uma morada provisória.

Se cair a chuva, a partir de qual momento é permitido deixar [a tenda]? Quando um prato de mingau se estragar [por causa da chuva].

Conta-se esta parábola: a que isto pode ser comparado? A um escravo que veio encher a taça do seu senhor, ele [o senhor] virou a jarra na sua cara.

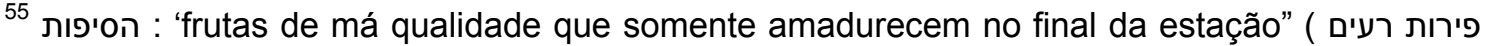
שאינם מבשלים אלא בסוף העונה Moshe Arye MIRKIN. Tel-Aviv: Ed. Yavne, 1956. Vol 1, p.166.

= מקפא = "a stiff nass of grist, oil and onions", segundo JASTROW, ibid, verbete מקפא, p. 831.

${ }^{57} \mathrm{O}$ melhor manuscrito conhecido da Mishná, Budapest Kaufman A 50, atesta a expressão conta-se este mashal. Cf. Site internet: Online treasury of Talmudic manuscripts: http://jnul.huji.ac.il/dl/talmud/ ad loc. Acesso em 29 de dezembro de 2009. É igualmente a lição do manuscrito Parma De Rossi 138 (mesmo site internet). A edição da Mishná por Albeck traz : משלו משל

58 קונה é sinônimo da palavra nashal anterior: dono, senhor, mestre. Os manuscritos Budapest Kaufman A 50 e Parma De Rossi 138 atestam a palavra קונה, enquanto a edição de Albeck apresenta o termo רב.
} 
6 MASHAL DOS PEIXES E DA RAPOSA (Talmud da Babilônia, tratado Berakhot 61b)

\author{
תנו רבנן 59

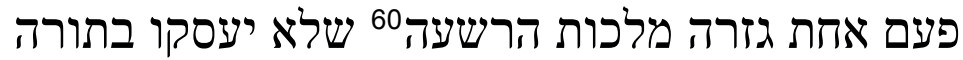

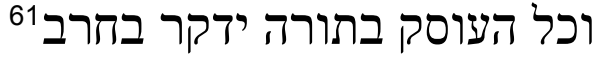

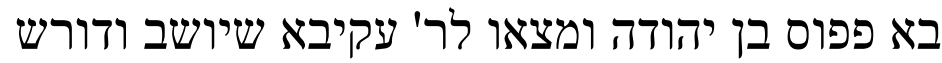

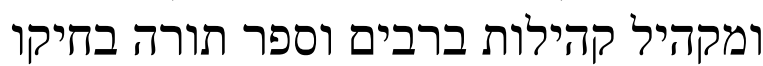

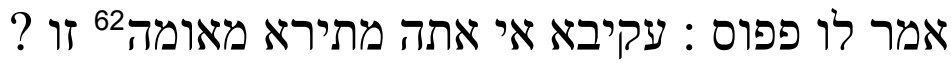

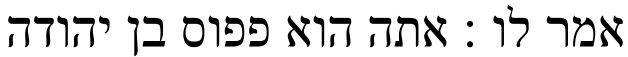 \\ שאומרים עליך חכם גדול? אי אתה אלא טפש. \\ אמשול לך משל למה הדבר דומה מהפה היחה \\ לשעול שהיה מהלך על שפת הים הים רמה ראה דגים דגים שמתקבצים64 \\ אמר להם למה אתם מתקוד מהבצים על מפתים \\ אמרו לו מפני הרשתות והמכמורות שתמבעים שעושין לנו בני אדם

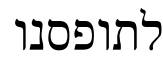 \\ אמר להם עלו ליבשה ונדור אני ואתם כדרך שדרו אבותי \\ ואבותיכם \\ אמרו לו אתה שועל שאומרים עליך פקח שבחיות, אי אתה אלא \\ שוטה

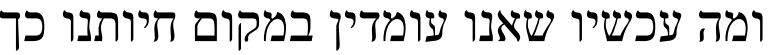 \\ אם אנו עולין ליבשה במקום מיתומיו במם עיותו על אחת כמה וכמה
}

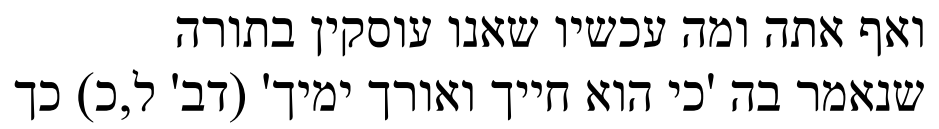

\footnotetext{
${ }^{59}$ Essa expressão técnica foi vista no mashal das roupas reais, parágrafo 3.3.1. Ela introduz uma baraita.

${ }^{60}$ Mss. Heb 95 e Heb 671 apresentam aqui uma lição interessante: גזרה מלכות הרשעה שמד על שראל שלא י..., i.e., 'o reino perverso decretou uma perseguição religiosa contra Israel'. A raiz do termo שמד expressa a destruição, a devastação, e por extensão, a apostasia. A expressão 'reino perverso' designa freqüentemente o império romano.

${ }^{61}$ Esta linha está atestada somente em Mss Oppenheim Add.23 e Paris Heb 671.

62 A palavra אומה pode ser traduzida por 'nação' ou mesmo 'governo'. Ela acaba sendo o sinônimo de goy, em oposição a Israel. Cf verbete אומה in: JASTROW, 1984,, p.26-27.

${ }^{63}$ Estas duas linhas [desde אמר לו ate não figuram na edição de Vilna que abranda a crítica a Papos ben Yehudá, evitando de chamá-lo de 'tolo'. Porém, o paralelo com o diálogo entre os peixes e a raposa, chamada de 'estúpida' parece impor-se. Estas duas linhas atestadas nos outros três manuscritos refletem provavelmente uma versão mais primitiva, ou menos expurgada.

${ }^{64}$ A edição de Vilna 'facilita' a compreensão acrescentando: מצקבצים ממקום למקום, 'se juntais de um lugar para outro'. E, de maneira ainda mais explícita, apresenta a seguinte lição logo em seguida: מפני מה אתם בורחים, 'de que vós fugis ?'
} 


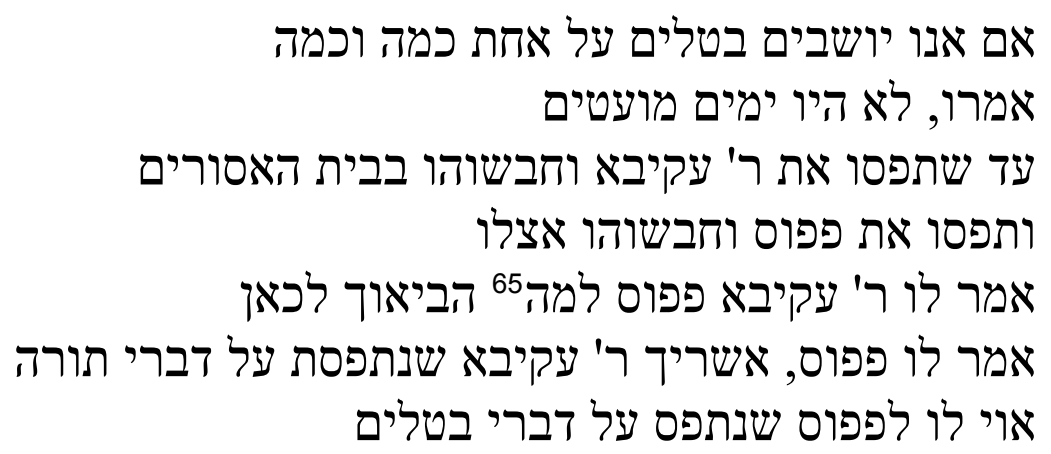

Nossos Mestres ensinaram:

aconteceu uma vez que o reino perverso [Roma] decretou que Israel não se ocuparia mais com a Torá

e aquele que se ocupasse da Torá seria passado a fio da espada.

Papos ben Yehudá foi visitar Rabi Aqiva e o encontrou sentado interpretando [a Torá],

fazendo assembléias públicas, e com um livro da Torá em seu colo.

Papos lhe disse:

"Aqiva, não tens medo deste governo [romano]?"

Ele respondeu-lhe:

"Não és tu Papos ben Yehudá, do qual dizem ser um grande sábio? Não passas de um tolo.

Vou contar-te uma parábola: a que isto é semelhante?

A uma raposa que caminhava à margem de um lago e que via peixes se juntando [em um lugar].

Ela Ihes disse: Porque vós vos juntais [em um lugar]?

Eles the disseram: por causa das redes e das armadilhas que fazem os humanos para prender-nos.

Ela Ihes disse: Subí para a terra seca e moraremos juntos, eu e vós, como moravam meus pais e os vossos pais.

Eles the disseram: Tu és a raposa da qual dizem ser a mais matreira de todos os animais? Não passas de uma estúpida! Se agora que estamos no nosso lugar vital é assim, pior será se subirmos para a terra seca, lugar da nossa morte!

Também para ti é assim: se agora que nos ocupamos com a Torá, da qual a Escritura diz (Dt 30,20):

\footnotetext{
${ }^{65}$ A lição da edição de Vilna é ממי הביאך לכאן, 'quem te trouxe aqui?', ao passo que os três manuscritos lêem: למה הביאוך לכאן, por que te trouxeram aqui ? Esta pergunta é muito mais incisiva, pois Papos decidiu abrir mão da Torá. Isso de nada adiantou.
} 
"Porque ele [sic] é tua vida e o prolongamento de teus dias", e [a situação] é assim, pior será se nós a abandonarmos!"

Conta-se que poucos dias depois, Aqiva foi detido e acorrentado na prisão.

Papos também foi preso e acorrentado perto de ele.

Rabi Aqiva Ihe disse: "Papos, por que te trouxeram aqui?"

Este Ihe respondeu: "Feliz és tu, Aqiva, que foste preso por causa das palavras da Torá!

Infeliz Papos que foi preso por causa de coisas vãs!" 